\title{
Upward Wealth Mobility: Exploring the Roman Catholic Advantage
}

\author{
Lisa A. Keister, Duke University
}

Wealth inequality is among the most extreme forms of stratification in the United States, and upward wealth mobility is not common. Yet mobility is possible, and this paper takes advantage of trends among a unique group to explore the processes that generate mobility. I show that non-Hispanic whites raised in Roman Catholic families have been upwardly mobile in the wealth distribution in recent decades, and I find that unique fertility, marriage and education patterns contributed to this change. I also show that Catholic values related to work and money contributed to relatively high saving and portfolio behavior that facilitated mobility. The results provide important insight into the process by which childhood experiences shape adult well-being, particularly adult wealth ownership. The findings also contribute to understanding of social inequality by identifying important behaviors and processes that facilitate mobility.

Wealth is among the most important measures of well-being because it is relatively enduring and related in some way to most other measures of achievement. Wealth - or net worth - is total household assets less total liabilities. For those who own it, wealth can enhance educational attainment, occupational opportunities, political influence and social advantages. It provides a buffer against income interruptions, medical emergencies and other crises such as accidents and natural disasters. Wealth can generate income in the form of interest and dividends, and it can create more wealth when it is reinvested. Wealth can also be passed to future generations to extend these benefits beyond those who initially accumulated it. Wealth ownership is highly concentrated and wealth mobility is rare at least in part because assets can be transferred across generations. In 2001, the top 1 percent of households owned 33 percent of net worth, while 18 percent of households had zero or negative net worth. ${ }^{1}$ The distribution of financial wealth is even more unequal. Financial wealth - net worth less net equity in owner occupied housing - is a measure of relatively liquid resources. In 2001, the top 1 percent of households owned 40 percent of financial wealth, and 26 percent of households had zero or negative financial assets. Prior to the 20th century, wealth mobility was extremely unusual, and even today, the majority of people

A grant from the National Institutes of Health (National Institutes on Aging, grant \#R01 AG24050-03) supported this work. I am grateful for research support from the Center for Advanced Study in the Behavioral Sciences and feedback from CASBS seminar participants. I am also grateful for research assistance from Matthew Painter and Alexis Yamokoski and for extremely helpful comments from Jimi Adams, Jackie Brooks, James Cavendish, Chris Ellison, Katherine Meyer, Jane Shealy, Darren Sherkat, and Chris Smith. Direct correspondence to Lisa A. Keister, Duke University, P.O. Box 90088, 268 Sociology/ Psychology Building Durham, NC 27708. E-mail: Lkeister@soc.duke.edu. 
do not change positions in the wealth distribution compared to their parents or over their adult lives (Keister 2005).

Yet whites raised in Roman Catholic families are likely to be an important recent example of an upwardly mobile group (Aizcorbe, Kennickell and Moore 2001; Keister 2005). Less than a generation ago, Roman Catholic families were relatively disadvantaged on a host of measures of well-being, particularly relative to Mainline Protestants (Glenn and Hyland 1967; Lenski 1961; Sherkat and Ellison 1999). In recent years, however, non-Hispanic whites raised in Catholic families have experienced dramatic changes in important demographic behaviors that contribute to wealth ownership including fertility, education and income. Preliminary evidence indicates that whites who were raised in Catholic families are no longer asset-poor and may even be among the wealthiest groups of adults in the United States today (Sherkat and Ellison 1999; Keister 2003, 2005). Although previous research identified Catholics as potentially mobile (Keister 2003, 2005), there has been no systematic investigation of the degree to which their wealth position has changed or, more importantly, of the factors that explain their mobility.

This research takes advantage of the unique opportunity created by changes among Roman Catholics to study wealth mobility. I isolate non-Hispanic whites who were raised in Roman Catholic families and identify the paths they followed during childhood and early adulthood to study the processes that generate mobility. ${ }^{2}$ Previous research is integrated to develop arguments about the nature of mobility for this distinctive group. I propose that unique demographic patterns among Catholics including declining fertility, advantageous marriage patterns, rising educational attainment, and a unique set of values regarding work and money contribute to their rising wealth. These ideas are tested using data from the National Longitudinal Survey of Youth 1979 cohort (NLS-Y). My analyses focus on wealth accumulation patterns in early adulthood because saving and accumulation during these years create the base that determines life-long wealth ownership.

\section{Catholics and Wealth Mobility}

Sociologists have debated the material consequences of religious affiliation for most of the 20th century (Darnell and Sherkat 1997; Featherman 1971; Greeley 1969; Lenski 1961). Weber (1930) and later Lenski (1961) asked important questions about how religious orientations shape stratification, and their proposals fueled strong interest in the subject through the 1960s and 1970s (Glenn and Hyland 1967; Roof 1979). Concern with the relationship between religion and material outcomes declined for a time, but it is experiencing a revival recently as improved data and methods allow researchers to isolate and study the relative importance of the many influences on well-being. It is now clear that religious orientation influences education, income, female labor force participation and careers, among a host of other important individual and family outcomes (Sherkat and Ellison 1999). Keister $(2003,2005)$ showed that religious affiliation and wealth ownership are related, and she demonstrated that Catholics currently have an advantage in wealth ownership that they lacked in earlier decades (Keister 2005, 
forthcoming). Yet what is missing is a clear account of the wealth position of Catholics compared to affiliates of other religious groups and an exploration of the factors that are responsible for that upward mobility.

There are, indeed, reasons to anticipate that religious affiliation shapes wealth ownership. Adult wealth ownership is a function of behaviors and strategies learned early in life that influence fertility, the timing and ordering of marriage, educational aspirations and attainment, job-related outcomes and attitudes toward saving. Religion affects many of these behaviors and processes, including fertility, marriage and divorce (Alwin 1986; Lehrer 1996; Sherkat and Ellison 1999), and education, female employment rates and earnings (Darnell and Sherkat 1997; Lehrer 1999; Wuthnow and Scott 1997). Religion may also affect saving behavior and portfolio composition directly. Children learn how to save from their families and other acquaintances, and religion can influence the financial lessons they learn. Religion shapes values and priorities and contributes to the set of competencies from which actions such as saving behavior is constructed (Keister 2003a; Swidler 1986). Nearly all churches and related religious organizations offer some guidance for living, often including specific tips for money management such as household budgeting, desirable expenditures and saving strategies. Together, these indirect and direct effects are likely to create a powerful influence of childhood processes on adult wealth ownership.

\section{Fertility, Family Size and Finances}

Family behaviors and outcomes are important predictors of wealth accumulation and mobility, and Catholic fertility patterns have changed in noteworthy ways in recent decades. Religion influences the onset of sexual activity, family formation, age at first birth and family size (Marcum 1981, 1986; Sherkat and Ellison 1999), and the relationship between religion and fertility has been particularly apparent among Catholics in recent decades. In prior generations, Catholics tended to have larger families than Protestants (Alwin 1986; Lenski 1961; Sherkat and Ellison 1999), but Catholics are now similar to Mainline Protestants in their propensity to remain childless and the age at which they have their first child (Lehrer 1996; Pearce forthcoming; Sherkat and Ellison 1999). In fact, total fertility for non-Hispanic white Catholics is now lower than for Mainline Protestants (Mosher, Williams and Johnson 1992; Sander 1995; Sherkat and Ellison 1999). Most Catholic adults are now two to three generations from immigration (Alba 1981), and distance from the immigrant experience is at least part of the reason for fertility changes (Borjas 1999, 2000). These changes, in turn, are likely to increase wealth ownership. Remaining childless is an extremely strong predictor of wealth ownership as children increase expenses that prevent saving. Delayed fertility also increases wealth because it facilitates educational attainment, career development, occupational advancement and initial saving and investing that can contribute to life-long asset appreciation (Keister 2005). Likewise, there is evidence that saving increases initially with family size as couples save for the added expenses associated with having children, but wealth declines precipitously after approximately two children 
as expenses increase and saving becomes more difficult (Keister 2005). Thus, I expect that foregone or delayed fertility and declining family size have contributed to upward mobility in wealth ownership for Catholics.

\section{Marriage and Money}

Marriage behavior is another critical determinant of wealth ownership, and Catholic marriage patterns are likely to facilitate accumulation. It has become clear that religious affiliation affects the likelihood of marriage (Hammond, Cole and Beck 1993; Mosher, Williams and Johnson 1992), the choice of a spouse (Lehrer 1998; Sherkat 2004), marital stability (Lehrer and Chiswick 1993), and the likelihood of divorce (Call and Heaton 1997; Filsinger and Wilson 1984). Catholics have particularly high marriage rates, high rates of marital stability, low divorce rates and exceptionally high rates of homogamy (Lehrer 1998; Sherkat 2004; Sherkat and Ellison 1999), and these patterns are likely to facilitate wealth accumulation. Marriage increases wealth because two individuals combine their assets when they create a single household. It also creates common goals (e.g., homeownership, retirement objectives) that encourage couples to save. Religious homogamy increases the likelihood that a couple has similar values, priorities and competences regarding finances. When those values favor saving as they do for Catholics, agreement can increase saving and wealth. Homogamy also reduces the likelihood of divorce for Catholics, contributing to even greater wealth (Curtis and Ellison 2002; Lehrer 1998; Sherkat 2004). Divorce tends to reduce wealth because assets are divided, couples maintain two households, and there may be direct costs such as legal fees associated with divorce. For these reasons, I expect that high marriage rates, marital stability and religious homogamy have contributed to upward mobility in wealth ownership for Catholics.

\section{Education}

Education is a third important determinant of wealth ownership, and Catholics have been highly upwardly mobile on nearly all education measures in recent decades. Religion affects orientations toward education and educational attainment (Darnell and Sherkat 1997; Lehrer 1999). As a result, religious background can shape both school quality and years of schooling completed. Both men and women raised in Catholic families have achieved levels of education comparable to those of people raised in Mainline Protestant families in recent years, even though Catholics tended to have parents who achieved relatively modest levels of education (Lehrer 1999; Sherkat and Ellison 1999). Distance from the immigrant experience may be part of the explanation for Catholic educational achievement (Borjas 1999, 2000). In addition, there are important advantages resulting from Catholic school attendance. Attending Catholic school is associated with higher test scores (Bryk, Lee and Hollan 1993; Hoffer, Greeley and Coleman 1985; Sander 1995), higher probabilities of completing high school and attending college (Evans and Schwab 1995; Neal 1997), increased rates of college graduation (Neal 1997), and higher adult salaries and wages (Neal 1997). ${ }^{3}$ The success of Catholic school students may result from stricter discipline, increased social capital produced by 
dense parental networks, and governance structures that allow for more parental choice and consensus than is possible in public schools (Coleman, Hoffer and Kilgore 1982a, 1982b). While not all people raised in Catholic families attended Catholic schools, the majority of those who were Catholic and elementary school age in the 1970s did. Some 60 percent of American Catholics surveyed in 1999 had attended Catholic school as a child for at least a short period of time, and 36 percent had attended seven or more years (D'Antonio, et al. 2001).

Moreover, many Catholic religious orders promote education in both their teachings and the activities they support (Coleman 1993; Greeley 2004). The Franciscans and Jesuits are particularly well known for their involvement in education, but devotion to running schools and colleges with secular as well as social and religious missions is central to nearly every Catholic religious order. The Catholic commitment to education originally developed as a way to deal with existential questions about human existence as early as the 1200s, and the tradition has remained an integral part of the faith since (Bryk, Lee and Hollan 1993). There is a history of Catholic immigrants to America encouraging their children to pursue educational opportunities, and from the late 1800s on, both male and female Catholics began to enter colleges and universities at increasing rates (Oats 1989). There are no apparent gender differences in lay educational pursuits; and if there are gender differences in educational success among Catholics, they favor girls (Bryk, Lee and Hollan 1993). There are certainly gender differences among Catholics, most apparent in the restriction on women becoming priests. Yet female religious leaders such as nuns pursue education themselves and contribute to Catholic education goals by becoming teachers and school administrators, and by pursuing other education-related careers (Hamington 1995). ${ }^{4}$

Upward educational mobility improves occupational outcomes including occupational prestige and income. Highly educated people also tend to experience greater career stability and enjoy greater benefits such as opportunities to save before taxes in instruments such as 403(b) accounts. Ultimately these patterns are likely to lead to wealth accumulation and upward wealth mobility. For these reasons, I expect that increasing educational attainment has contributed to upward wealth mobility for Catholics.

\section{Work and Money: Values and Mobility}

Religion can also influence wealth ownership directly by shaping the values that people use to make work and financial decisions (Keister 2003a; Swidler 1986). Values are ideals that express the worth associated with actions and outcomes, and the shared cultural understandings that accompany religious belief are an important determinant of values. Religious beliefs attribute value to the act of working, to working for certain organizations, and to working in some occupations. Religious beliefs also attribute value to money, saving, sacrificial giving and other behaviors that directly involve money. The values associated with work and financial behaviors vary dramatically by religious belief, but there is little question that money is meaningful, that values and finances are intimately connected, and that Americans recognize there is a connection (Wuthnow 1994; Zelizer 1978, 1989). 


\section{6 - Social Forces Volume 85, Number 3 • March 2007}

There is evidence that Catholics tend to have unique values related to work and money, and these values are likely to shape their saving behavior and wealth accumulation patterns. Compared to other religious groups, for example, Catholics tend to have an instrumental attitude toward work. That is, there is evidence that Catholics approach work as an activity that produces a result rather than something that is pleasurable in itself (Tropman 1995, 2002). Work is a way to earn money to buy necessary things. Catholics also tend to have a strong orientation toward family, and their motivation to work is extrinsic, usually oriented toward the family (Tropman 2002). Again, some of this family orientation may derive from the recent immigrant experience and the strong ethnic ties that immigration involved (Borjas 1999, 2000). While white nonHispanic Catholics have largely assimilated, there is some evidence that the strong family focus has persisted (Tropman 2002). Although an instrumental attitude toward work might reduce the incentive to work, the added effect of a strong family orientation has lead Catholics to work relatively hard (D'Antonio, et al. 2001; Greeley 1979). They may satisfice at work (Tropman 1995) - that is, Catholics may work only as long or as hard as necessary to provide for their families - but they nonetheless work hard (D'Antonio, et al. 2001). Egalitarian gender roles suggest that there are also likely to be two earners in Catholic households with two adults (Oats 1989), and wealth research shows that having two earners is an important predictor of asset accumulation (Keister 2005). Together, hard work and having two earners suggests that Catholics will have sufficient income to save and accumulate assets.

Similarly, Catholics have an instrumental attitude toward money. As with work, there is evidence that Catholics tend to see money as a means to acquire necessities (Tropman 1995, 2002). Money is necessary to meet needs, but it is only a tool rather than something with intrinsic value (DeBerri and Hug 2003; Thibodeau, O'Donnell and O'Connor 1997). Again, the strong family orientation is important in speculating about how this value will shape wealth ownership. Catholics tend to save in order to care for their families (Tropman 2002). That is, while an instrumental view of money might reduce saving, having a strong extrinsic motivation will, in contrast, lead Catholics to save and invest in ways that will ensure their families are secure. This suggests that there should be a direct effect of religious affiliation on wealth for Catholics.

In addition, their instrumental attitude toward money suggests that Catholics will save in ways that are relatively low-risk. For example, Catholics are likely to prefer homeownership and stable financial investments (e.g., investments with guaranteed rates of return from banks) to volatile financial investments (e.g., stocks) because they can meet their needs without unnecessarily risking their capital. In addition, the Catholic Church does not have a strong tradition of tithing that would dilute the amount of income available to save in Catholic families (Chaves and Miller 1999; D'Antonio, et al. 2001). There is some evidence that Catholics are community-oriented (Greeley 1989; Tropman 2002), and they may be relatively more likely to volunteer and otherwise be generous (Nelson and Greene 2003; Regnerus, Smith and Sikkink 1998). Yet there is little evidence that tithing reduces their disposable income in a way that would slow wealth 
accumulation (Steen 1996). For these reasons, I expect that values related to work and money increase saving, particularly in relatively stable investments, and have contributed to upward wealth mobility for Catholics.

\section{Data}

I explored these ideas empirically using the 1979-2000 National Longitudinal Survey of Youth (NLS-Y). The Bureau of Labor Statistics administered the first NLS-Y to a nationally-representative sample of 12,686 young adults (ages 14 to 22 ) in 1979. They conducted follow-up surveys yearly until 1994 and biennially until 2000 when respondents were ages 35 to 43. This study uses data on 4,753 non-Hispanic white non-immigrants from the NLS-Y core sample. ${ }^{5}$ The NLS-Y includes detailed information about family background, transitions to adulthood and adult traits. It also contains detailed religious affiliation data and a comprehensive series of asset and debt questions that were added in 1985 when the youngest respondents were age $20 .{ }^{6}$ The NLS-Y wealth modules ask respondents if they own a series of assets and debts and, for those who are owners, the current value. Data from all survey years are used to create independent variables, and data from 12 years are used as dependent variables (1985-1990, 1992, 1993, 1995, 1996, 1998, 2000). These data are ideal for this study because they are longitudinal, include a large representative sample, and contain detailed information about religion and wealth.

\section{Measures}

\section{Dependent Variables}

First, I modeled family background traits - father's education, mother's education and inheritances received - to examine arguments that Catholics were relatively disadvantaged in previous generations. Father's and mother's educations were dichotomous indicators that the respondent's biological father or biological mother had ever earned a bachelor's degree or more education. ${ }^{7}$ The inheritance measure was a dichotomous variable indicating that the respondent had ever received an inheritance. I modeled parents' education in 1979 as a function of other relevant family characteristics, including religious affiliation, in the same year. Inheritance in 2000 captures all intergenerational transfers through the most recent survey year and controlled for religious background and other factors that might affect transfers. ${ }^{8}$

Second, I modeled adult wealth using measures of total net worth, ownership and value of the primary residence, ownership and value of checking and savings accounts (i.e., cash accounts), and ownership and value of stocks. Each dependent in the respondent's adult family is measured for every survey year from 1985 through 2000, and net worth is quantified as total financial and real assets less total liabilities. ${ }^{9}$ The financial assets included stocks and bonds, checking and savings accounts, trust accounts, Individual Retirement Accounts, $401 \mathrm{k}$ plans and Certificates of Deposit. The real assets included the primary residence, businesses, farms, investment real estate, vehicles and other 
possessions. ${ }^{10}$ The liabilities included mortgages on the primary residence; debt on businesses, farms and investment real estate; vehicle debt; and other debt such as consumer debt and student loans. ${ }^{11}$ Net assets is skewed as wealth ownership is concentrated in the hands of a relatively small portion of the population. Yet, logging the variable, double logging it, taking the square root, and otherwise transforming it did not reduce the skew because a large portion of households has zero net assets. Because using logged wealth and removing those with zero net worth did not change the results, I report results of analyses using un-logged net assets to ease interpretation. ${ }^{12}$

\section{Religion Variables}

Childhood religious affiliation is determined with a series of dichotomous indicators created from 1979 reports of childhood religion. ${ }^{13}$ Measures for Catholic, Mainline Protestant, Conservative Protestant, Jewish, other religion and no religion are included. I followed Steensland, et al. (2002) in defining the Protestant groups. Conservative Protestants include members of churches with traditional theological beliefs who accept the Bible as the inerrant Word of God, value personal conversion experiences and emphasize the importance of the Christian faith to social issues (e.g., Assembly of God, Churches of Christ, Pentecostal, Southern Baptist). In contrast, Mainline Protestants are members of churches with more liberal theologies that tend to accept social change more freely (e.g., Lutheran, United Methodist, Presbyterian).

I varied the omitted category for religion across analyses to explore arguments about Catholic mobility. Previous research suggests that Conservative Protestants tend to come from low status families and have relatively low adult wealth (nearly half the national median), while Mainline Protestants come from high status families and have comparatively high wealth (Keister 2003a, 2005; Sherkat and Ellison 1999). In my analyses of family background, I first compare Catholics to Conservative Protestants, then to Mainline Protestants. Separate models explore the argument that Catholics come from relatively disadvantaged backgrounds. If the data support this argument, Catholics will have backgrounds that are less advantaged than Mainline Protestants and relatively comparable to those of Conservative Protestants. In models of adult wealth, Conservative Protestants are omitted to explore the argument that Catholics have been upwardly mobile. If the data support this argument, Catholics will have wealth that is greater than that of Conservative Protestants (i.e., positive and significant coefficient estimate) and at least comparable to Mainline Protestants (i.e., coefficient estimate of comparable magnitude).

\section{Test Variables}

Fertility is measured with fourvariables: a dichotomous indicator that the respondent had any children, and continuous indicators of the respondent's age at first birth, the number of children born and the number of children born squared. The square of the number of children captures the curvilinear relationship between family size and wealth. ${ }^{14}$ Marriage behavior is measured with a dichotomous indicator 
that the respondent was ever married, a continuous indicator of the number of marital transitions (i.e., changes in marital status) the respondent experienced prior to the current year and a dichotomous indicator that the respondent and spouse were both raised in Catholic families. ${ }^{15}$ Marital status in the current year is controlled with dichotomous variables indicating whether the respondent was married, separated, divorced or widowed. A series of education dummy variables measures whether the respondent had completed high school, some college, a college degree or an advanced degree. ${ }^{16} \mathrm{I}$ also included a continuous indicator of the total household income (logged) and a dichotomous measure indicating whether there were two income earners in the household.

\section{Control Variables}

I included several family background indicators to control for other characteristics of the family of origin that affect adult wealth ownership. Parents' income in 1978 (logged) is a continuous measure of total household income in the family of origin. A dummy variable indicates that the respondent did not provide information about family income in 1978 to control for patterns that might be common to those with missing values on this key variable (Sandefur and Wells 1999). Two dummy variables give a snapshot of the respondent's family structure at age 14 and a measure of childhood family size. Previous literature suggests that both financial resources and non-financial resources (such as parents' time) are diluted in large families, and each additional sibling diminishes adult attainment (Downey 1995; Keister 2003b). The total number of siblings the respondent ever had indicates family size in childhood. Parents' education is measured with a series of dichotomous variables indicating the highest level of education attained by the respondent's biological father and biological mother. Dichotomous variables indicate whether the respondent's parents both worked fulltime (more than 35 hours per week) in 1978 as a gauge of work ethics. I also include measures of parents' immigrant status. I controlled for the receipt of inheritances and the amount inherited where appropriate ${ }^{17}$ and recorded gender and age in years. ${ }^{18}$

Geography can also shape asset values, particularly home values and affect net worth. To control for the influence of geography, I used a series of dichotomous indicators of the respondent's region of residence. Three dichotomous variables (lagged one year) indicating whether the respondent lived in a north central, a southern or a western state. Northeastern states were omitted because Catholics have tended to be concentrated in those states. I also included a single indicator of urban residence in order to capture urban-rural differences in wealth ownership. ${ }^{19}$ This variable uses census data to indicate whether the county of residence had a central core city and adjacent, closely-settled area with a total combined population of 50,000 or more.

Table 1 contains means and standard deviations for the control variables. The estimates in this table are for the sample included in the analyses. The values are consistent with other sources of demographic information for the U.S. population in both the late 1970s and 2000, including the General Social Survey. Finally, Variance Inflation Factors (VIFs) suggest that correlated independent variables are not affecting my estimates. 
Table 1: Descriptive Statistics for Exogenous Variables, NLS-Y 2000

\begin{tabular}{|c|c|c|c|c|}
\hline \multicolumn{4}{|c|}{ Mean (S.D.) } & \multirow{2}{*}{$\begin{array}{c}\text { Mean (S.D.) } \\
\$ 15,850.00 \\
(\$ 15,900.00\end{array}$} \\
\hline Catholic & $\begin{array}{r}.32 \\
(.46)\end{array}$ & Parents' incc & me & \\
\hline Mainline Protestant & $\begin{array}{l}.29 \\
(.45)\end{array}$ & Stepparent $f$ & amily & $\begin{array}{c}.08 \\
(.27)\end{array}$ \\
\hline Conservative Protestant & $\begin{array}{l}.30 \\
(.31)\end{array}$ & Single-paren & t family & $\begin{array}{l}.10 \\
(.30)\end{array}$ \\
\hline Jewish & $\begin{array}{l}.02 \\
(.13)\end{array}$ & Number of $\mathrm{s}$ & iblings & $\begin{array}{c}2.74 \\
(2.02)\end{array}$ \\
\hline Other religion & $\begin{array}{l}.03 \\
(.15)\end{array}$ & Father: Hig & h school & $\begin{array}{l}.35 \\
(.48)\end{array}$ \\
\hline No religion & $\begin{array}{l}.04 \\
(.20)\end{array}$ & Son & ne college & $\begin{array}{l}.11 \\
(.32)\end{array}$ \\
\hline Have any children & $\begin{array}{c}.81 \\
(.39)\end{array}$ & Col & ege degree & $\begin{array}{l}.11 \\
(.31)\end{array}$ \\
\hline Age at first birth & $\begin{array}{l}25.40 \\
(5.30)\end{array}$ & Adv & anced degree & $\begin{array}{l}.07 \\
(.16)\end{array}$ \\
\hline Number of children & $\begin{array}{l}1.40 \\
(1.20)\end{array}$ & Mother: Hig & h school & $\begin{array}{l}.49 \\
(.50)\end{array}$ \\
\hline Ever married & $\begin{array}{l}.71 \\
(.45)\end{array}$ & & ne college & $\begin{array}{l}.11 \\
(.32)\end{array}$ \\
\hline Number of marital changes & $\begin{array}{l}1.20 \\
(2.00)\end{array}$ & & lege degree & $\begin{array}{l}.08 \\
(.27)\end{array}$ \\
\hline Both Catholic & $\begin{array}{c}.21 \\
(.41)\end{array}$ & & vanced degree & $\begin{array}{l}.03 \\
(.16)\end{array}$ \\
\hline Married & $\begin{array}{l}.55 \\
(.50)\end{array}$ & Father work & d fulltime & $\begin{array}{l}.82 \\
(.39)\end{array}$ \\
\hline Separated & $\begin{array}{l}.03 \\
(.16)\end{array}$ & Mother work & ed fulltime & $\begin{array}{l}.39 \\
(.49)\end{array}$ \\
\hline Divorced & $\begin{array}{l}.12 \\
(.33)\end{array}$ & Father born & in the U.S. & $\begin{array}{l}.90 \\
(.19)\end{array}$ \\
\hline Widowed & $\begin{array}{l}.004 \\
(.06)\end{array}$ & Mother born & in the U.S. & $\begin{array}{l}.91 \\
(.18)\end{array}$ \\
\hline High school & $\begin{array}{l}.43 \\
(.48)\end{array}$ & Ever inherite & & $\begin{array}{r}.10 \\
(.53)\end{array}$ \\
\hline Some college & $\begin{array}{l}.21 \\
(.38)\end{array}$ & Amount inhe & rited & $\begin{array}{r}\$ 2,454.00 \\
(\$ 21,162.00)\end{array}$ \\
\hline College degree & $\begin{array}{l}.16 \\
(.34)\end{array}$ & Residence: & Northeast & $\begin{array}{r}.16 \\
\text { (.34) }\end{array}$ \\
\hline Advanced degree & $\begin{array}{c}.12 \\
(.29)\end{array}$ & & North central & $\begin{array}{l}.23 \\
(.43)\end{array}$ \\
\hline Family income & $\begin{array}{c}\$ 65,075.00 \\
(\$ 58,530.00)\end{array}$ & & South & $\begin{array}{c}.41 \\
(.46)\end{array}$ \\
\hline Two earner household & $\begin{array}{c}.30 \\
(.44)\end{array}$ & & West & $\begin{array}{r}.20 \\
(.35)\end{array}$ \\
\hline Male & $\begin{array}{l}.49 \\
(.50)\end{array}$ & & Urban & $\begin{array}{l}.62 \\
(.48)\end{array}$ \\
\hline Age & $\begin{array}{l}39.40 \\
(2.20)\end{array}$ & & & \\
\hline
\end{tabular}

Notes: $\mathrm{n}=4,753$ non-Hispanic white non-immigrants. Parents' income is in current 1978 dollars; converted to 2000 dollars using the CPI: mean $=\$ 38,200($ S.D. $=\$ 40,100)$. Education is highest level completed. 


\section{Modeling Strategy}

To model parents' education and inheritance, I used logistic regression models in which the dependent variables were measured in 2000 and independent variables were measured in either 1979 or 2000 . To study changes in wealth between 1985 and 2002, a pooled cross-section time series data set was created with person-years as the unit of analysis. Thus, the data set included one observation per respondent per year for 1985 through 2000, and both the dependent and independent variables were able to vary yearly for each respondent. Logistic regression modeled home ownership, cash account ownership and stock ownership between 1985 and 2000. I used likelihood-based general linear regression in SAS Proc Mixed to model net worth between 1985 and 2000 because the error terms were both heteroskedastic and correlated over time. ${ }^{20}$ The mixed model is written as:

$$
\mathrm{Y}=\mathrm{X} \beta+\mathrm{Z} \gamma+\epsilon
$$

where $Y$ is a matrix of outcome variables, $X$ is a matrix of independent variables, $\beta$ is a matrix of fixed-effect parameters to be estimated, $\mathrm{Z}$ is a known design matrix, and $\gamma$ is a vector of unknown random-effects parameters. ${ }^{21}$ The estimator option is used to correct for heteroskedasticity following Diggle, Liang and Zeger (1994), and I assumed an AR(1) structure across years to correct for autocorrelation.

\section{Results: Catholics are Upwardly Mobile}

The results provide support for each of my arguments. Both descriptive statistics and multivariate analyses provide strong evidence that non-Hispanic whites raised in Catholic families have been upwardly mobile. Table 2 compares respondents' parents' education levels, an important indicator of family socioeconomic status, by religion. The table separates respondents into those who reported being raised in Catholic, Mainline Protestant and Conservative Protestant families. ${ }^{22}$ The results show that Catholics' fathers and mothers were less educated than the parents of Mainline Protestants but more educated than the parents of conservative Protestants. ${ }^{23}$ Similarly, fewer Catholics than Mainline Protestants ever inherited, but more Catholics than Conservative Protestants ever inherited. Yet Catholic adult wealth is comparable to, or greater than, Mainline Protestant adult wealth, providing initial evidence of upward mobility. Median net worth for Catholics is nearly identical to that of Mainline Protestants, the mean is higher for Catholics reflecting a small number of very wealthy Catholics.

Table 3 includes results of logistic regression models predicting three indicators of family status in childhood: father's education, mother's education and inheritance. For each dependent variable, results are reported with two different omitted categories for Catholics: first Conservative Protestants, then Mainline Protestants. Models 1 and 2 show that, controlling for other important predictors, in 1979 Catholics were significantly more likely than Conservative Protestants, but less likely than Mainline Protestants, to have a father who had 
Table 2: Childhood Religion and Adult Wealth Ownership, NLS-Y 2000

\begin{tabular}{lccccc}
\hline & $\begin{array}{c}\text { Father } \\
\text { had BA }\end{array}$ & $\begin{array}{c}\text { Mother } \\
\text { had BA }\end{array}$ & $\begin{array}{c}\text { Ever } \\
\text { inherited }\end{array}$ & $\begin{array}{c}\text { Net worth, } \\
\text { mean }\end{array}$ & $\begin{array}{c}\text { Net worth, } \\
\text { median }\end{array}$ \\
\hline All respondents & $11.0 \%$ & $8.1 \%$ & $10.2 \%$ & $\$ 255.6$ & $\$ 65.0$ \\
$\begin{array}{l}\text { Childhood religion } \\
\text { Catholic }\end{array}$ & 9.2 & 7.1 & 8.0 & 179.8 & 82.0 \\
$\begin{array}{l}\text { Mainline } \\
\text { Protestant }\end{array}$ & 13.7 & 10.1 & 12.3 & 159.2 & 81.0 \\
$\begin{array}{l}\text { Conservative } \\
\text { Protestant }\end{array}$ & 5.8 & 4.3 & 3.5 & 107.6 & 41.6 \\
\hline
\end{tabular}

Notes: $\mathrm{n}=4,753$ non-Hispanic white non-immigrants. Values are thousands of 2000 dollars.

completed college or an advanced degree. Similarly, Models 3 and 4 show that Catholics were significantly more likely than Conservative Protestants, but less likely than Mainline Protestants, to have a mother who had completed college or more education. Models 5 and 6 show that Catholics were more likely than Conservative Protestants, and less likely than Mainline Protestants, to ever inherit. While parents' education and inheritance are not the only indicators of well-being in childhood, they are essential components of social status that capture much of the variance in overall well-being. Moreover, using other measures of childhood status (e.g., family income, parents' occupational prestige) produced similar results. Taken together, these results provide important evidence that Catholics were raised in relatively disadvantaged families.

Yet Catholics have experienced relatively high levels of intragenerational wealth mobility. That is, non-Hispanic whites raised in Catholic families have moved up in the wealth distribution more rapidly than average. Table 4 compares the percentage of Catholics who were upwardly mobile between 1985 and 2000 to the percentage of the entire NLS-Y cross sectional sample who were upwardly mobile. ${ }^{24}$ First shown is the percentage of respondents who moved from the bottom quintile of the distribution of wealth (i.e., net worth, or total assets less total debts) to either of the top two quintiles of the distribution. Of those in the full sample, 22.8 percent were in the bottom quintile of wealth owners in 1985 and in one of the top two quintiles in 2000. For Catholics, the number of upwardly mobile respondents was 32.6 percent. Similarly, a significantly larger percentage of Catholics moved from the second quintile (34.4 percent) and third quintile (43.4 percent) to either the fourth or fifth quintiles. The results are comparable if movement in the distribution at comparable ages (e.g., between ages 25 and 35 or between ages 35 and 45 for those with valid data for each year) is compared. As the NLS-Y sample continues to age, their wealth will increase and these differences are likely to become even more pronounced. 
Table 3: Logistic Models of Family Background Traits, NLS-Y 1979-2000

\begin{tabular}{|c|c|c|c|c|c|c|}
\hline \multirow{2}{*}{$\begin{array}{r}\text { Education } \\
\text { Model }\end{array}$} & \multicolumn{2}{|c|}{ Father's Education } & \multicolumn{2}{|c|}{ Mother's Education } & \multicolumn{2}{|c|}{ Ever Inherited } \\
\hline & 1 & 2 & 3 & 4 & 5 & 6 \\
\hline \multicolumn{7}{|l|}{ Childhood religion } \\
\hline Catholic & $\begin{array}{l}.54^{* * *} \\
(.05)\end{array}$ & $\begin{array}{l}-.43^{\star * *} \\
(.04)\end{array}$ & $\begin{array}{l}.60^{* * *} \\
(.09)\end{array}$ & $\begin{array}{l}-.69^{* * *} \\
(.07)\end{array}$ & $\begin{array}{l}.19^{* * *} \\
(.03)\end{array}$ & $\begin{array}{l}-.10^{* * *} \\
(.03)\end{array}$ \\
\hline Mainline Protestant & $\begin{array}{l}.96^{* *} \\
(.05)\end{array}$ & - & $\begin{array}{l}1.29^{* * *} \\
(.08)\end{array}$ & - & $\begin{array}{l}.28^{\star * *} \\
(.03)\end{array}$ & - \\
\hline Conservative Protestant & - & $\begin{array}{l}-.99^{* * *} \\
(.05)\end{array}$ & - & $\begin{array}{c}-1.30^{* * *} \\
(.08)\end{array}$ & - & $\begin{array}{l}-.29^{* * *} \\
(.03)\end{array}$ \\
\hline Jewish & $\begin{array}{l}2.19^{* * *} \\
(.08)\end{array}$ & $\begin{array}{l}1.22^{* * *} \\
(.08)\end{array}$ & $\begin{array}{l}1.77^{* * *} \\
(.16)\end{array}$ & $\begin{array}{l}.48^{* * *} \\
(.15)\end{array}$ & $\begin{array}{l}1.25^{\star * *} \\
(.13)\end{array}$ & $\begin{array}{l}.96^{* * *} \\
(.13)\end{array}$ \\
\hline Other religion & $\begin{array}{l}1.89^{* * *} \\
(.08)\end{array}$ & $\begin{array}{l}.92^{* * *} \\
(.08)\end{array}$ & $\begin{array}{l}2.20^{* * *} \\
(.12)\end{array}$ & $\begin{array}{l}.91^{* * *} \\
(.11)\end{array}$ & $\begin{array}{l}.46^{* * *} \\
(.08)\end{array}$ & $\begin{array}{l}.18^{*} \\
(.08)\end{array}$ \\
\hline No religion & $\begin{array}{l}.79^{* * *} \\
(.08)\end{array}$ & $\begin{array}{l}-.17^{*} \\
(.08)\end{array}$ & $\begin{array}{l}1.64^{* * *} \\
(.12)\end{array}$ & $\begin{array}{l}.35^{\star * *} \\
(.10)\end{array}$ & $\begin{array}{c}.08 \\
(.05)\end{array}$ & $\begin{array}{l}-.20^{\text {*** }} \\
(.05)\end{array}$ \\
\hline Have any children & - & - & - & - & $\begin{array}{l}-.04 \\
(.03)\end{array}$ & $\begin{array}{l}-.04 \\
(.03)\end{array}$ \\
\hline \multicolumn{7}{|l|}{ Marital status } \\
\hline Married & - & - & - & - & $\begin{array}{l}.02 \\
(.02)\end{array}$ & $\begin{array}{l}.02 \\
(.02)\end{array}$ \\
\hline Separated & - & - & - & - & $\begin{array}{l}-.06 \\
(.06)\end{array}$ & $\begin{array}{l}-.06 \\
(.06)\end{array}$ \\
\hline Divorced & - & - & - & - & $\begin{array}{l}.09^{* *} \\
(.03)\end{array}$ & $\begin{array}{l}.09^{* *} \\
(.03)\end{array}$ \\
\hline Widowed & - & - & - & - & $\begin{array}{l}.77^{\star * *} \\
(.16)\end{array}$ & $\begin{array}{l}.77^{* * *} \\
(.16)\end{array}$ \\
\hline \multicolumn{7}{|l|}{ Education } \\
\hline High school & - & - & - & - & $\begin{array}{l}.47^{* * *} \\
(.03)\end{array}$ & $\begin{array}{l}.47^{* * *} \\
(.03)\end{array}$ \\
\hline Some college & - & - & - & - & $\begin{array}{l}.78^{* * *} \\
(.04)\end{array}$ & $\begin{array}{l}.78^{* * *} \\
(.04)\end{array}$ \\
\hline College degree & - & - & - & - & $\begin{array}{l}1.14^{* * *} \\
(.04)\end{array}$ & $\begin{array}{l}1.14^{* * *} \\
(.04)\end{array}$ \\
\hline Advanced degree & - & - & - & - & $\begin{array}{l}1.48^{* * *} \\
(.05)\end{array}$ & $\begin{array}{l}1.48^{\text {*** }} \\
(.05)\end{array}$ \\
\hline \multicolumn{7}{|l|}{ Financial resources } \\
\hline Family income (log) & - & - & - & - & $\begin{array}{l}.02^{*} \\
(.01)\end{array}$ & $\begin{array}{l}.02^{*} \\
(.01)\end{array}$ \\
\hline Two earner household & - & - & - & - & $\begin{array}{l}.01^{* * *} \\
(.00)\end{array}$ & $\begin{array}{l}.01^{* * *} \\
(.00)\end{array}$ \\
\hline Family background & & & & & & \\
\hline Parents' income (log) & $\begin{array}{l}.04^{* * *} \\
(.01)\end{array}$ & $\begin{array}{l}.04^{* * *} \\
(.01)\end{array}$ & $\begin{array}{l}-.01 \\
(.01)\end{array}$ & $\begin{array}{l}-.01 \\
(.01)\end{array}$ & $\begin{array}{l}.01^{* * *} \\
(.00)\end{array}$ & $\begin{array}{l}.01^{* * *} \\
(.00)\end{array}$ \\
\hline
\end{tabular}


Table 3 continued

\begin{tabular}{|c|c|c|c|c|c|c|}
\hline \multicolumn{7}{|l|}{$\begin{array}{l}\text { Family structure at age } \\
14\end{array}$} \\
\hline Stepparent family & $\begin{array}{l}-.77^{* * *} \\
(.08)\end{array}$ & $\begin{array}{l}-.77^{* * *} \\
(.08)\end{array}$ & $\begin{array}{l}-.87^{* * *} \\
(.15)\end{array}$ & $\begin{array}{l}-.87^{* * *} \\
(.15)\end{array}$ & $\begin{array}{l}.12^{* *} \\
(.04)\end{array}$ & $\begin{array}{l}.12^{* *} \\
(.04)\end{array}$ \\
\hline Single-parent family & $\begin{array}{l}.08 \\
(.06)\end{array}$ & $\begin{array}{l}.08 \\
(.06)\end{array}$ & $\begin{array}{l}.79^{* * *} \\
(.07)\end{array}$ & $\begin{array}{l}.79^{* * *} \\
(.07)\end{array}$ & $\begin{array}{l}.16^{* * *} \\
(.04)\end{array}$ & $\begin{array}{l}.16^{* * *} \\
(.04)\end{array}$ \\
\hline Number of siblings & $\begin{array}{l}-.13^{* * *} \\
(.01)\end{array}$ & $\begin{array}{l}-.13^{\star * *} \\
(.01)\end{array}$ & $\begin{array}{l}-.18^{* * *} \\
(.02)\end{array}$ & $\begin{array}{l}-.18^{* * *} \\
(.02)\end{array}$ & $\begin{array}{l}-.03^{* * *} \\
(.01)\end{array}$ & $\begin{array}{l}-.03^{\text {** }} \\
(.01)\end{array}$ \\
\hline \multicolumn{7}{|l|}{ Father's education } \\
\hline High school & - & - & - & - & $\begin{array}{l}.23^{* * *} \\
(.03)\end{array}$ & $\begin{array}{l}.23^{* * *} \\
(.03)\end{array}$ \\
\hline Some college & - & - & - & - & $\begin{array}{l}.03 \\
(.04)\end{array}$ & $\begin{array}{l}.03 \\
(.04)\end{array}$ \\
\hline College degree & - & - & - & - & $\begin{array}{l}.44^{* * *} \\
(.04)\end{array}$ & $\begin{array}{l}.44^{* * *} \\
(.04)\end{array}$ \\
\hline Advanced degree & - & - & - & - & $\begin{array}{l}.83^{* * *} \\
(.05)\end{array}$ & $\begin{array}{l}.83^{\text {*** }} \\
(.05)\end{array}$ \\
\hline \multicolumn{7}{|l|}{ Mother's education } \\
\hline High school & - & - & - & - & $\begin{array}{l}.07^{* *} \\
(.03)\end{array}$ & $\begin{array}{l}.07^{* *} \\
(.03)\end{array}$ \\
\hline Some college & - & - & - & - & $\begin{array}{l}.33^{* * *} \\
(.04)\end{array}$ & $\begin{array}{l}.33^{\text {*** }} \\
(.04)\end{array}$ \\
\hline College degree & - & - & - & - & $\begin{array}{l}.45^{* * *} \\
(.05)\end{array}$ & $\begin{array}{l}.45^{\star \star *} \\
(.05)\end{array}$ \\
\hline Advanced degree & - & - & - & - & $\begin{array}{l}.21^{* *} \\
(.08)\end{array}$ & $\begin{array}{l}.21^{* *} \\
(.08)\end{array}$ \\
\hline Father worked fulltime & $\begin{array}{l}.60 \\
(.05)\end{array}$ & $\begin{array}{l}.60 \\
(.05)\end{array}$ & $\begin{array}{l}.07 \\
(.07)\end{array}$ & $\begin{array}{l}.07 \\
(.07)\end{array}$ & $\begin{array}{l}-.09^{* *} \\
(.03)\end{array}$ & $\begin{array}{l}-.09^{* *} \\
(.03)\end{array}$ \\
\hline Mother worked fulltime & $\begin{array}{l}-.23 \\
(.03)\end{array}$ & $\begin{array}{l}-.23 \\
(.03)\end{array}$ & $\begin{array}{l}1.04 \\
(.06)\end{array}$ & $\begin{array}{l}1.04 \\
(.06)\end{array}$ & $\begin{array}{c}.03 \\
(.02)\end{array}$ & $\begin{array}{c}.03 \\
(.02)\end{array}$ \\
\hline Father born in U.S. & $\begin{array}{l}-.08 \\
(.08)\end{array}$ & $\begin{array}{l}-.08 \\
(.08)\end{array}$ & $\begin{array}{l}-.05 \\
(.12)\end{array}$ & $\begin{array}{l}-.05 \\
(.12)\end{array}$ & $\begin{array}{l}.32^{* * *} \\
(.06)\end{array}$ & $\begin{array}{l}.32^{* * *} \\
(.06)\end{array}$ \\
\hline Mother born in U.S. & $\begin{array}{l}-.30 \\
(.08)\end{array}$ & $\begin{array}{l}-.30 \\
(.08)\end{array}$ & $\begin{array}{l}-.30 \\
(.12)\end{array}$ & $\begin{array}{l}-.30 \\
(.12)\end{array}$ & $\begin{array}{l}-.18^{* *} \\
(.06)\end{array}$ & $\begin{array}{l}-.18^{* *} \\
(.06)\end{array}$ \\
\hline \multicolumn{7}{|l|}{ Current residence } \\
\hline North central & - & - & - & - & $\begin{array}{l}-.22^{* * *} \\
(.03)\end{array}$ & $\begin{array}{l}-.22^{* * *} \\
(.03)\end{array}$ \\
\hline South & - & - & - & - & $\begin{array}{l}-.24^{* * *} \\
(.03)\end{array}$ & $\begin{array}{l}-.23^{* * *} \\
(.03)\end{array}$ \\
\hline West & - & - & - & - & $\begin{array}{l}-.06 \\
(.04)\end{array}$ & $\begin{array}{l}-.06 \\
(.04)\end{array}$ \\
\hline Urban & - & - & - & - & $\begin{array}{l}.24^{* * *} \\
(.02)\end{array}$ & $\begin{array}{l}.24^{* * *} \\
(.02)\end{array}$ \\
\hline$\underline{x}^{2}$ & $2,018^{* * *}$ & $2,038^{* * *}$ & $1,345^{* * *}$ & $1,343^{* * *}$ & $5,480^{* * *}$ & $5,484^{* * *}$ \\
\hline
\end{tabular}

Notes: Standard errors are in parentheses. Sample is 4,753 non-Hispanic white non-immigrants. Also controlled but not displayed are age, gender, and a dichotomous indicator that the respondent did not report childhood family income.

${ }^{*} \mathrm{p}<.05 \quad{ }^{* *} \mathrm{p}<.01 \quad{ }^{* * *} \mathrm{p}<.001$ 
Table 4: Wealth Mobility: Catholics vs. All Respondents, NLS-Y 1985-2000

\begin{tabular}{lcc}
\hline & All & \\
& Respondents & Catholics \\
\hline Quintile 1 to Quintile 4 or 5 & 22.8 & $32.6^{* * *}$ \\
Quintile 2 to Quintile 4 or 5 & 27.4 & $34.4^{* *}$ \\
Quintile 3 to Quintile 4 or 5 & 38.0 & $43.4^{* *}$ \\
\hline
\end{tabular}

Notes: $\mathrm{n}=4,753$ non-Hispanic white non-immigrants. Cells indicate the percent of respondents who were in the first quintile in the distribution of net worth in 1985 and in the either of the second quintiles in 2000.

${ }^{* *} \mathrm{p}<.01{ }^{* * *} \mathrm{p}<.001$

\section{Results}

\section{Fertility Facilitates Mobility}

An important part of the story underlying Catholic wealth mobility is changing fertility patterns. Table 5 presents multivariate models of net worth to examine the role of fertility and other inputs. In all multivariate models, Conservative Protestants is the omitted category and control for being raised Mainline Protestant in order to compare the position of Catholics relative to both groups. The first model in Table 5 shows that Catholics have an important wealth advantage controlling only for individual attributes and other relevant family background factors such as parents' education, family income and family structure. The coefficient estimate for Catholic is positive and significant, and it is larger than the coefficient for Mainline Protestant. Table 3 suggested that Catholics grew up in lower status families compared to Mainline Protestants, but Table 5 provides evidence that Catholics have equal or greater adult wealth than Mainline Protestants. Although the descriptive statistics in Table 2 suggest that average wealth for Catholics and Mainline Protestants is comparable, the multivariate results in Table 5 suggest that people raised in Catholic families have significantly more wealth than we would expect by chance given their other background traits.

Table 5, Model 2 introduces measures of respondent's fertility, marriage behavior and education. The measure for having any children is negative and comparatively quite large, and the effect of age at first birth is positive and significant. Similarly, the coefficient estimate for the number of children ever born is positive, while its square is negative and significant. Each of these patterns is consistent with other research that shows that children reduce wealth (Keister 2005). More important, the effect of a Catholic upbringing on adult wealth is weaker in Model 2 of Table 5 than in the basic model (Model 1). ${ }^{25}$ This finding is consistent with other research on the advantages Catholics have in earnings (Lehrer 1996) and provides support for my proposal that fertility patterns contributed to mobility for Catholics. Table 5, Model 3 introduces additional control, including measures of inheritance. Even with this large and comprehensive set of control variables, being raised in a Catholic family is a strong and significant predictor of adult wealth. Notably the effect of being Catholic remains larger than the effect of being raised Mainline Protestant. 
16 - Social Forces Volume 85, Number 3 • March 2007

Table 5: General Linear Model Estimates of Net Worth, NLS-Y 1985-2000

\begin{tabular}{|c|c|c|c|}
\hline & Model 1 & Model 2 & Model 3 \\
\hline \multicolumn{4}{|l|}{ Childhood religion } \\
\hline Catholic & $\begin{array}{l}23.17^{* * *} \\
(5.41)\end{array}$ & $\begin{array}{l}16.86^{* *} \\
(5.97)\end{array}$ & $\begin{array}{l}14.34^{*} \\
(7.01)\end{array}$ \\
\hline Mainline Protestant & $\begin{array}{l}15.70^{*} \\
(6.18)\end{array}$ & $\begin{array}{c}7.98 \\
(6.65)\end{array}$ & $\begin{array}{c}4.23 \\
(9.27)\end{array}$ \\
\hline Jewish & $\begin{array}{c}100.94^{* *} \\
(41.89)\end{array}$ & $\begin{array}{l}102.22^{* *} \\
(46.33)\end{array}$ & $\begin{array}{l}107.57^{*} \\
(70.06)\end{array}$ \\
\hline Other religion & $\begin{array}{c}5.39 \\
(23.30)\end{array}$ & $\begin{array}{c}1.56 \\
(26.50)\end{array}$ & $\begin{array}{l}-22.66 \\
(29.47)\end{array}$ \\
\hline No religion & $\begin{array}{c}10.36 \\
(16.76)\end{array}$ & $\begin{array}{c}19.06 \\
(17.10)\end{array}$ & $\begin{array}{c}25.66 \\
(24.13)\end{array}$ \\
\hline \multicolumn{4}{|l|}{ Fertility } \\
\hline Have any children & - & $\begin{array}{c}-104.71^{* * *} \\
(20.95)\end{array}$ & $\begin{array}{c}-100.34^{* * *} \\
(27.80)\end{array}$ \\
\hline Age at first birth & - & $\begin{array}{l}3.66^{* * *} \\
(.69)\end{array}$ & $\begin{array}{l}3.19^{* * *} \\
(.88)\end{array}$ \\
\hline Number of children & - & $\begin{array}{l}33.33^{* * *} \\
(5.95)\end{array}$ & $\begin{array}{l}25.90^{* * *} \\
(7.72)\end{array}$ \\
\hline Number of children (square) & - & $\begin{array}{l}-4.28^{* * *} \\
(1.29)\end{array}$ & $\begin{array}{l}-2.87^{\star *} \\
(1.56)\end{array}$ \\
\hline \multicolumn{4}{|l|}{ Marriage } \\
\hline Ever married & - & $\begin{array}{l}32.04^{* * *} \\
(7.43)\end{array}$ & $\begin{array}{c}22.57^{*} \\
(11.56)\end{array}$ \\
\hline Number of marital changes & - & $\begin{array}{c}-12.11^{* *} \\
(5.63)\end{array}$ & $\begin{array}{r}-12.42^{*} \\
(8.53)\end{array}$ \\
\hline Both Catholic & - & $\begin{array}{l}14.70 \text { ** } \\
(6.74)\end{array}$ & $\begin{array}{l}13.24 \\
(9.39)\end{array}$ \\
\hline Married & - & - & $\begin{array}{l}13.06^{* *} \\
(8.31)\end{array}$ \\
\hline Separated & - & - & $\begin{array}{c}-5.27 \\
(16.60)\end{array}$ \\
\hline Divorced & - & - & $\begin{array}{l}-10.77 \\
(12.41)\end{array}$ \\
\hline Widowed & - & - & $\begin{array}{c}43.77 \\
(34.70)\end{array}$ \\
\hline \multicolumn{4}{|l|}{ Education } \\
\hline High school & - & $\begin{array}{l}27.39^{\star * *} \\
(5.50)\end{array}$ & $\begin{array}{l}22.99 * * \\
(7.07)\end{array}$ \\
\hline Some college & - & $\begin{array}{l}43.30^{* * *} \\
(7.67)\end{array}$ & $\begin{array}{l}35.18^{* * *} \\
(9.67)\end{array}$ \\
\hline College degree & - & $\begin{array}{l}61.47^{* * *} \\
(9.22)\end{array}$ & $\begin{array}{l}53.85^{* * *} \\
(11.72)\end{array}$ \\
\hline Advanced degree & - & $\begin{array}{l}65.75^{\star * *} \\
(12.74)\end{array}$ & $\begin{array}{c}52.23^{* *} \\
(16.41)\end{array}$ \\
\hline
\end{tabular}


Table 5 continued

\begin{tabular}{|c|c|c|c|}
\hline \multicolumn{4}{|l|}{ Financial resources } \\
\hline Family income (log) & - & - & $\begin{array}{l}14.86^{* * *} \\
(3.43)\end{array}$ \\
\hline Two earner household & - & - & $\begin{array}{c}.41^{*} \\
(.16)\end{array}$ \\
\hline \multicolumn{4}{|l|}{ Family background } \\
\hline Parents' income (log) & $\begin{array}{l}1.99^{*} \\
(.81)\end{array}$ & $\begin{array}{l}1.23 \\
(.94)\end{array}$ & $\begin{array}{c}.56 \\
(1.30)\end{array}$ \\
\hline Stepparent family & $\begin{array}{l}-9.26 \\
(7.89)\end{array}$ & $\begin{array}{c}1.03 \\
(8.61)\end{array}$ & $\begin{array}{c}3.46 \\
(11.42)\end{array}$ \\
\hline Single-parent family & $\begin{array}{c}3.31 \\
(7.57)\end{array}$ & $\begin{array}{c}6.68 \\
(7.42)\end{array}$ & $\begin{array}{c}6.64 \\
(9.71)\end{array}$ \\
\hline Number of siblings & $\begin{array}{l}-3.63^{\star *} \\
(1.21)\end{array}$ & $\begin{array}{l}-3.67^{*} \\
(1.44)\end{array}$ & $\begin{array}{l}-2.99 \\
(2.06)\end{array}$ \\
\hline \multicolumn{4}{|l|}{ Father's education } \\
\hline High school & $\begin{array}{l}17.09^{* *} \\
(5.88)\end{array}$ & $\begin{array}{c}10.72 \\
(6.40)\end{array}$ & $\begin{array}{c}7.43 \\
(8.72)\end{array}$ \\
\hline Some college & $\begin{array}{c}20.36^{*} \\
(9.72)\end{array}$ & $\begin{array}{c}11.96 \\
(10.26)\end{array}$ & $\begin{array}{c}7.34 \\
(13.87)\end{array}$ \\
\hline College degree & $\begin{array}{l}37.31^{* *} \\
(11.33)\end{array}$ & $\begin{array}{c}23.91 \\
(13.36)\end{array}$ & $\begin{array}{c}24.39 \\
(18.02)\end{array}$ \\
\hline Advanced degree & $\begin{array}{l}49.56^{* *} \\
(15.58)\end{array}$ & $\begin{array}{c}30.99 \\
(17.01)\end{array}$ & $\begin{array}{c}34.03 \\
(22.85)\end{array}$ \\
\hline \multicolumn{4}{|l|}{ Mother's education } \\
\hline High school & $\begin{array}{c}4.74 \\
(6.05)\end{array}$ & $\begin{array}{l}-4.01 \\
(6.49)\end{array}$ & $\begin{array}{l}-3.71 \\
(8.75)\end{array}$ \\
\hline Some college & $\begin{array}{r}22.43^{*} \\
(10.41)\end{array}$ & $\begin{array}{c}9.52 \\
(11.37)\end{array}$ & $\begin{array}{c}9.88 \\
(14.29)\end{array}$ \\
\hline College degree & $\begin{array}{c}44.67^{*} \\
(15.36)\end{array}$ & $\begin{array}{r}37.48^{*} \\
(16.88)\end{array}$ & $\begin{array}{c}48.98^{*} \\
(22.56)\end{array}$ \\
\hline Advanced degree & $\begin{array}{c}15.02 \\
(17.75)\end{array}$ & $\begin{array}{c}5.02 \\
(19.22)\end{array}$ & $\begin{array}{c}12.82 \\
(26.84)\end{array}$ \\
\hline Father worked fulltime & $\begin{array}{l}14.55^{* *} \\
(6.05)\end{array}$ & $\begin{array}{l}12.90^{*} \\
(6.46)\end{array}$ & $\begin{array}{l}16.44 \\
(8.81)\end{array}$ \\
\hline Mother worked fulltime & $\begin{array}{l}-4.54 \\
(4.91)\end{array}$ & $\begin{array}{l}-6.98 \\
(5.29)\end{array}$ & $\begin{array}{r}-10.53 \\
(7.09)\end{array}$ \\
\hline Father born in U.S. & $\begin{array}{l}-20.99 \\
(13.50)\end{array}$ & $\begin{array}{l}-18.45 \\
(14.62)\end{array}$ & $\begin{array}{l}-18.82 \\
(16.36)\end{array}$ \\
\hline Mother born in U.S. & $\begin{array}{l}-13.51 \\
(18.16)\end{array}$ & $\begin{array}{l}-17.55 \\
(18.96)\end{array}$ & $\begin{array}{l}-31.51 \\
(24.57)\end{array}$ \\
\hline Ever inherited & - & - & $\begin{array}{l}19.63^{* *} \\
(7.26)\end{array}$ \\
\hline Amount inherited & - & - & $\begin{array}{l}.01^{* *} \\
(.00)\end{array}$ \\
\hline
\end{tabular}


Table 5 continued

\begin{tabular}{lccc}
\hline Current residence & & & \\
North central & - & - & -10.09 \\
& & & $(11.18)$ \\
South & - & - & .79 \\
& & & $(13.00)$ \\
West & - & - & 2.38 \\
& & & $(13.43)$ \\
Urban & - & - & -1.79 \\
& & & $(6.62)$ \\
$\chi^{2}$ & $7,573^{* * *}$ & $7,850^{* * *}$ & $8,353^{* * *}$ \\
\hline
\end{tabular}

Notes: Standard errors are in parentheses. Models include 4,753 non-Hispanic white non-immigrants or 57,036 $\left(4,753^{\star} 12\right.$ years $)$ observations. Also controlled but not displayed are age, gender, and a dichotomous indicator that the respondent did not report childhood family income.

${ }^{*} \mathrm{p}<.05 \quad{ }^{* *} \mathrm{p}<.01 \quad{ }^{* * *} \mathrm{p}<.001$

\section{The Marriage Advantage}

I also proposed that Catholic marriage behavior has contributed to wealth accumulation and mobility. Model 2 of Table 5 introduces family traits and fertility measures to the model of adult net worth. Consistent with this and prior research, the indicator that the respondent was ever married is positive and significant, and the indicator of the number of marital transitions prior to the current year is negative and significant. Likewise, the indicator of marital homogamy is positive and significant. Controlling for all three variables in the same equation enables this study to appropriately model homogamy and transitions for those who have never been married without assigning missing values to those respondents. I do not include a control for respondents who were ever divorced because the effect is captured by the measure of transitions. However, in separate models (not shown), the measure of ever divorced produces results that are consistent with other findings reported here. The introduction of these variables reduces the strength of the effect of the variable indicating that the respondent was raised in a Catholic family. ${ }^{26}$ Table 5, Model 3 introduces other adult control variables, and the Catholic effect remains strong. Table 5, Model 4 also introduces controls for current marital status. These additional control variables reduce the effect of the other marriage indicators because there is a degree of overlap in the processes that the variables capture. Yet the religion effect remains strong.

\section{Education and Wealth Mobility}

The results also provide support for my argument that increasing educational attainment among Catholics has contributed to upward mobility. Non-Hispanic whites raised in Catholic families have achieved rather exceptional levels of education mobility in recent decades (Sherkat and Ellison 1999), and education 
is one of the strongest predictors of wealth accumulation (Keister 2005). Table 5, Model 2 introduces measures of respondent's education and demonstrates that education accounts for part of the Catholic advantage in adult wealth ownership. ${ }^{27}$ This finding is consistent with other research on the advantages Catholics have in earnings (Lehrer 1996) and provides support for my proposal that educational mobility contributed to wealth mobility for Catholics. Upward educational mobility improves occupational outcomes including occupational prestige and income. Highly educated people also tend to experience greater career stability and enjoy greater benefits such as opportunities to save before taxes in instruments such as 403(b) accounts. Subsequent models introduce additional adult controls, and the effect of education remains strong and significant as prior research suggests it should. Again, however, the effect of being raised Catholic remains strong even with the most restrictive control variables (e.g., inheritance) in the model.

\section{Work, Money and Mobility}

I also argued that Catholics also have distinctive attitudes toward work and money that can lead to unique work behavior and that can affect wealth accumulation directly. In Table 5, Model 3 introduces the dichotomous measure for dual earner households and the continuous measure of household income. Both measures are strong, positive and statistically significant. Introducing these measures also reduces the strength of the Catholic indicator, providing support for the argument that these work patterns contribute to the strength of the effect of being raised Catholic. ${ }^{28}$

In addition, results provide support for my argument that saving and investment behavior contributed to wealth mobility for non-Hispanic whites raised in Catholic families. I proposed that distinctive saving and investment behavior would produce a direct effect of being Catholic on wealth ownership. The final model in Table 5 provides support for that argument. There may be other factors that contribute to the direct effect, but finding a direct effect of religion after controlling for a comprehensive set of other influences is a necessary condition for arguing that the results support my proposal.

Finally, I find that Catholics' own a unique combination of assets and have an instrumental attitude toward money that may lead them to save in relatively lowrisk ways. Table 6 includes six additional models of the some key components of total wealth that explore this argument. The table includes logistic models of three dichotomous dependent variables (the home, saving and checking accounts, and stock/mutual fund ownership) and general linear models of three linear dependent variables (home value, cash account value, value of stocks and bonds). Each model includes the religion measures (Conservative Protestant is the omitted category again) and all control variables including family background, education and adult variables. The results show that Catholics are more likely than both Conservative Protestants and Mainline Protestants to own a home and cash accounts (e.g., checking and savings accounts). Both of these assets are considered low risk, while stocks and related financial instruments are higher risk assets. The value of the housing and cash assets that Catholics own is significantly 
Table 6: Asset Ownership and Value, NLS-Y 1985-2000

\begin{tabular}{|c|c|c|c|c|c|c|}
\hline & $\begin{array}{c}\text { Home } \\
\text { Ownership }\end{array}$ & $\begin{array}{l}\text { Home } \\
\text { Value }\end{array}$ & $\begin{array}{l}\text { Cash acct } \\
\text { Ownership }\end{array}$ & $\begin{array}{c}\text { Cash acct } \\
\text { Value }\end{array}$ & $\begin{array}{c}\text { Stock } \\
\text { Ownership }\end{array}$ & $\begin{array}{l}\text { Stock } \\
\text { Value }\end{array}$ \\
\hline \multicolumn{7}{|c|}{ Childhood religion } \\
\hline Catholic & $\begin{array}{l}.13^{* *} \\
(.04)\end{array}$ & $\begin{array}{l}14.05^{\text {*** }} \\
(2.64)\end{array}$ & $\begin{array}{l}.33^{\star * *} \\
(.05)\end{array}$ & $\begin{array}{l}3.89^{* *} \\
(1.40)\end{array}$ & $\begin{array}{l}.22^{\star * \star} \\
(.04)\end{array}$ & $\begin{array}{c}1.76 \\
(2.55)\end{array}$ \\
\hline Mainline Protestant & $\begin{array}{l}.09^{*} \\
(.04)\end{array}$ & $\begin{array}{c}4.72 \\
(2.45)\end{array}$ & $\begin{array}{l}.23^{* * *} \\
(.04)\end{array}$ & $\begin{array}{c}2.34 \\
(1.43)\end{array}$ & $\begin{array}{l}.12^{* *} \\
(.04)\end{array}$ & $\begin{array}{c}1.49 \\
(2.46)\end{array}$ \\
\hline Jewish & $\begin{array}{l}-.36^{* *} \\
(.13)\end{array}$ & $\begin{array}{r}32.68^{*} \\
(15.69)\end{array}$ & $\begin{array}{l}-.19 \\
(.19)\end{array}$ & $\begin{array}{c}19.64 \\
(13.30)\end{array}$ & $\begin{array}{l}.30^{*} \\
(.12)\end{array}$ & $\begin{array}{l}15.55^{\star * *} \\
(5.20)\end{array}$ \\
\hline Other religion & $\begin{array}{l}-.31^{* *} \\
(.11)\end{array}$ & $\begin{array}{l}-9.09 \\
(7.66)\end{array}$ & $\begin{array}{l}-.03 \\
(.12)\end{array}$ & $\begin{array}{c}14.95 \\
(15.30)\end{array}$ & $\begin{array}{l}-.17 \\
(.12)\end{array}$ & $\begin{array}{l}-4.98 \\
(6.61)\end{array}$ \\
\hline No religion & $\begin{array}{l}.04 \\
(.07)\end{array}$ & $\begin{array}{c}6.91 \\
(4.53)\end{array}$ & $\begin{array}{c}.09 \\
(.07)\end{array}$ & $\begin{array}{c}24.11 \\
(12.93)\end{array}$ & $\begin{array}{l}.03 \\
(.08)\end{array}$ & $\begin{array}{c}8.28 \\
(5.93)\end{array}$ \\
\hline Fertility & & & & & & \\
\hline Have any children & $\begin{array}{l}-.36^{* *} \\
(.12)\end{array}$ & $\begin{array}{c}-35.27^{* * *} \\
(6.90)\end{array}$ & $\begin{array}{c}-1.45^{\star * *} \\
(.13)\end{array}$ & $\begin{array}{l}-8.03 \\
(7.81)\end{array}$ & $\begin{array}{c}-1.37^{* * *} \\
(.14)\end{array}$ & $\begin{array}{r}-19.48^{*} \\
(8.22)\end{array}$ \\
\hline Age at first birth & $\begin{array}{l}.01^{* *} \\
(.00)\end{array}$ & $\begin{array}{l}1.38^{* * *} \\
(.25)\end{array}$ & $\begin{array}{l}.04^{* * *} \\
(.00)\end{array}$ & $\begin{array}{c}.37 \\
(.26)\end{array}$ & $\begin{array}{l}.05^{* * *} \\
(.00)\end{array}$ & $\begin{array}{l}.67^{* *} \\
(.23)\end{array}$ \\
\hline No. children & $\begin{array}{l}.47^{* * *} \\
(.04)\end{array}$ & $\begin{array}{l}10.87^{* * *} \\
(1.48)\end{array}$ & $\begin{array}{l}.11^{*} \\
(.04)\end{array}$ & $\begin{array}{c}-.08 \\
(2.27)\end{array}$ & $\begin{array}{l}.19^{* * *} \\
(.04)\end{array}$ & $\begin{array}{c}5.40 \\
(3.03)\end{array}$ \\
\hline No. children (square) & $\begin{array}{l}-.08^{* * *} \\
(.01)\end{array}$ & $\begin{array}{c}-1.15^{\star *} \\
(.38)\end{array}$ & $\begin{array}{l}-.04^{\star * *} \\
(.01)\end{array}$ & $\begin{array}{l}-.16 \\
(.44)\end{array}$ & $\begin{array}{l}-.03^{\star * *} \\
(.01)\end{array}$ & $\begin{array}{l}-.50 \\
(.77)\end{array}$ \\
\hline Marriage & & & & & & \\
\hline Ever married & $\begin{array}{l}.25^{\star \star *} \\
(.06)\end{array}$ & $\begin{array}{l}8.89^{* *} \\
(3.25)\end{array}$ & $\begin{array}{l}.08 \\
(.06)\end{array}$ & $\begin{array}{r}8.67^{*} \\
(4.09)\end{array}$ & $\begin{array}{l}-.06 \\
(.06)\end{array}$ & $\begin{array}{c}1.02 \\
(3.31)\end{array}$ \\
\hline No. marital changes & $\begin{array}{l}-.16^{* *} \\
(.05)\end{array}$ & $\begin{array}{c}-.82 \\
(1.37)\end{array}$ & $\begin{array}{l}-.01 \\
(.06)\end{array}$ & $\begin{array}{l}-2.52 \\
(1.81)\end{array}$ & $\begin{array}{l}.02 \\
(.06)\end{array}$ & $\begin{array}{l}-2.90 \\
(1.72)\end{array}$ \\
\hline Both Catholic & $\begin{array}{l}.06 \\
(.04)\end{array}$ & $\begin{array}{l}11.37^{* * *} \\
(2.59)\end{array}$ & $\begin{array}{l}.11^{*} \\
(.04)\end{array}$ & $\begin{array}{c}-.01 \\
(2.92)\end{array}$ & $\begin{array}{l}-.05 \\
(.04)\end{array}$ & $\begin{array}{l}-3.49 \\
(2.24)\end{array}$ \\
\hline Married & $\begin{array}{l}1.38^{\star * *} \\
(.04)\end{array}$ & $\begin{array}{c}26.34^{* * *} \\
(1.45)\end{array}$ & $\begin{array}{l}.64^{\star * *} \\
(.05)\end{array}$ & $\begin{array}{l}-2.51 \\
(3.59)\end{array}$ & $\begin{array}{l}.16^{\star * *} \\
(.05)\end{array}$ & $\begin{array}{l}3.61^{* * *} \\
(1.50)\end{array}$ \\
\hline Separated & $\begin{array}{l}-.44^{\star * *} \\
(.08)\end{array}$ & $\begin{array}{l}-6.27 \\
(5.56)\end{array}$ & $\begin{array}{l}-.39^{* * *} \\
(.08)\end{array}$ & $\begin{array}{l}-5.84^{*} \\
(2.32)\end{array}$ & $\begin{array}{l}-.44^{* * *} \\
(.11)\end{array}$ & $\begin{array}{c}-.43 \\
(5.38)\end{array}$ \\
\hline Divorced & $\begin{array}{l}-.16^{* * *} \\
(.04)\end{array}$ & $\begin{array}{l}-4.64 \\
(2.58)\end{array}$ & $\begin{array}{l}-.15^{\star *} \\
(.05)\end{array}$ & $\begin{array}{l}-4.91 \\
(3.02)\end{array}$ & $\begin{array}{l}-.09 \\
(.05)\end{array}$ & $\begin{array}{c}2.75 \\
(3.34)\end{array}$ \\
\hline Widowed & $\begin{array}{l}.66^{* *} \\
(.21)\end{array}$ & $\begin{array}{c}29.33 \\
(16.43)\end{array}$ & $\begin{array}{c}.26 \\
(.22)\end{array}$ & $\begin{array}{l}-2.67 \\
(7.26)\end{array}$ & $\begin{array}{l}.18 \\
(.25)\end{array}$ & $\begin{array}{c}2.18 \\
(5.62)\end{array}$ \\
\hline Education & & & & & & \\
\hline High school & $\begin{array}{l}.56^{\star * *} \\
(.06)\end{array}$ & $\begin{array}{l}11.33^{* * *} \\
(2.37)\end{array}$ & $\begin{array}{l}.71^{* * *} \\
(.05)\end{array}$ & $\begin{array}{r}5.70^{*} \\
(2.39)\end{array}$ & $\begin{array}{l}.61^{* * *} \\
(.10)\end{array}$ & $\begin{array}{c}1.07 \\
(1.43)\end{array}$ \\
\hline Some college & $\begin{array}{l}.58^{\star * *} \\
(.06)\end{array}$ & $\begin{array}{l}16.29^{* * *} \\
(3.04)\end{array}$ & $\begin{array}{l}1.02^{* * *} \\
(.06)\end{array}$ & $\begin{array}{c}.70 \\
(1.58)\end{array}$ & $\begin{array}{l}.88^{* * *} \\
(.11)\end{array}$ & $\begin{array}{c}.36 \\
(2.33)\end{array}$ \\
\hline College degree & $\begin{array}{l}.70^{\star * *} \\
(.07)\end{array}$ & $\begin{array}{l}38.48^{* * *} \\
(4.02)\end{array}$ & $\begin{array}{l}1.62^{* * *} \\
(.08)\end{array}$ & $\begin{array}{l}6.16^{* *} \\
(2.17)\end{array}$ & $\begin{array}{l}1.31^{* * *} \\
(.11)\end{array}$ & $\begin{array}{l}9.70^{* *} \\
(2.96)\end{array}$ \\
\hline Advanced degree & $\begin{array}{l}.44^{\star * *} \\
(.08)\end{array}$ & $\begin{array}{l}34.77^{* * *} \\
(4.52)\end{array}$ & $\begin{array}{l}1.64^{* * *} \\
(.09)\end{array}$ & $\begin{array}{c}9.34^{*} \\
(3.70)\end{array}$ & $\begin{array}{l}1.25^{\star * *} \\
(.11)\end{array}$ & $\begin{array}{l}11.06^{*} \\
(5.13)\end{array}$ \\
\hline
\end{tabular}


Table 6 continued

\begin{tabular}{|c|c|c|c|c|c|c|}
\hline \\
\hline Family income (log) & $\begin{array}{l}.26^{\star * *} \\
(.02)\end{array}$ & $\begin{array}{l}3.43^{* * *} \\
(.35)\end{array}$ & $\begin{array}{l}.32^{* * *} \\
(.01)\end{array}$ & $\begin{array}{l}3.02^{\star * *} \\
(.87)\end{array}$ & $\begin{array}{l}.56^{* * *} \\
(.02)\end{array}$ & $\begin{array}{l}3.01^{* * *} \\
(.69)\end{array}$ \\
\hline Two-earner household & $\begin{array}{l}.00^{* * *} \\
(.00)\end{array}$ & $\begin{array}{l}.27^{\star * *} \\
(.05)\end{array}$ & $\begin{array}{l}.01^{* * *} \\
(.00)\end{array}$ & $\begin{array}{l}-.04 \\
(.05)\end{array}$ & $\begin{array}{l}.00^{* * *} \\
(.00)\end{array}$ & $\begin{array}{l}.03 \\
(.04)\end{array}$ \\
\hline \multicolumn{7}{|l|}{ Family background } \\
\hline Parents' income (log) & $\begin{array}{l}.00 \\
(.00)\end{array}$ & $\begin{array}{l}1.36^{\star \star \star} \\
(.29)\end{array}$ & $\begin{array}{l}.01 \\
(.00)\end{array}$ & $\begin{array}{l}.02 \\
(.31)\end{array}$ & $\begin{array}{l}-.01 \\
(.00)\end{array}$ & $\begin{array}{l}-.33 \\
(.40)\end{array}$ \\
\hline Stepparent family & $\begin{array}{l}-.12^{*} \\
(.05)\end{array}$ & $\begin{array}{l}-1.98 \\
(3.25)\end{array}$ & $\begin{array}{l}-.02 \\
(.06)\end{array}$ & $\begin{array}{l}-5.63^{*} \\
(2.21)\end{array}$ & $\begin{array}{c}.07 \\
(.06)\end{array}$ & $\begin{array}{l}-4.30^{* *} \\
(1.40)\end{array}$ \\
\hline Single-parent family & $\begin{array}{l}-.16^{\star *} \\
(.05)\end{array}$ & $\begin{array}{l}-4.31 \\
(3.00)\end{array}$ & $\begin{array}{l}-.12^{*} \\
(.06)\end{array}$ & $\begin{array}{l}-5.31 \\
(3.09)\end{array}$ & $\begin{array}{l}-.09 \\
(.06)\end{array}$ & $\begin{array}{c}-.41 \\
(2.76)\end{array}$ \\
\hline No. of siblings & $\begin{array}{l}-.03^{* * *} \\
(.00)\end{array}$ & $\begin{array}{r}-1.24^{*} \\
(.50)\end{array}$ & $\begin{array}{l}-.02^{*} \\
(.01)\end{array}$ & $\begin{array}{c}.06 \\
(.59)\end{array}$ & $\begin{array}{l}-.03^{* * *} \\
(.01)\end{array}$ & $\begin{array}{c}.51 \\
(.70)\end{array}$ \\
\hline \multicolumn{7}{|l|}{ Father's education } \\
\hline High school & $\begin{array}{l}-.06 \\
(.04)\end{array}$ & $\begin{array}{r}5.03^{*} \\
(2.36)\end{array}$ & $\begin{array}{l}.05 \\
(.04)\end{array}$ & $\begin{array}{c}5.33 \\
(2.77)\end{array}$ & $\begin{array}{c}.00 \\
(.04)\end{array}$ & $\begin{array}{l}-1.07 \\
(2.07)\end{array}$ \\
\hline Some college & $\begin{array}{l}-.22^{* * *} \\
(.05)\end{array}$ & $\begin{array}{c}.68 \\
(3.53)\end{array}$ & $\begin{array}{l}.01 \\
(.06)\end{array}$ & $\begin{array}{c}6.40 \\
(3.86)\end{array}$ & $\begin{array}{l}.18^{* *} \\
(.05)\end{array}$ & $\begin{array}{c}3.02 \\
(4.87)\end{array}$ \\
\hline College degree & $\begin{array}{l}-.06 \\
(.06)\end{array}$ & $\begin{array}{l}12.94^{* *} \\
(4.55)\end{array}$ & $\begin{array}{l}.18^{*} \\
(.08)\end{array}$ & $\begin{array}{c}6.48 \\
(3.46)\end{array}$ & $\begin{array}{l}.28^{* * *} \\
(.06)\end{array}$ & $\begin{array}{c}3.84 \\
(5.31)\end{array}$ \\
\hline Advanced degree & $\begin{array}{l}-.19^{* *} \\
(.07)\end{array}$ & $\begin{array}{l}8.57 \\
(5.30)\end{array}$ & $\begin{array}{l}.18 \\
(.10)\end{array}$ & $\begin{array}{c}-.89 \\
(3.49)\end{array}$ & $\begin{array}{l}.20^{* *} \\
(.07)\end{array}$ & $\begin{array}{c}.49 \\
(6.32)\end{array}$ \\
\hline \multicolumn{7}{|l|}{ Mother's education } \\
\hline High school & $\begin{array}{l}.09^{*} \\
(.04)\end{array}$ & $\begin{array}{c}3.41 \\
(2.27)\end{array}$ & $\begin{array}{l}.14^{\star * *} \\
(.04)\end{array}$ & $\begin{array}{l}-2.29 \\
(2.83)\end{array}$ & $\begin{array}{l}.27^{\star * *} \\
(.04)\end{array}$ & $\begin{array}{c}.87 \\
(2.06)\end{array}$ \\
\hline Some college & $\begin{array}{l}.23^{* * *} \\
(.06)\end{array}$ & $\begin{array}{r}9.78^{*} \\
(3.92)\end{array}$ & $\begin{array}{l}.10 \\
(.07)\end{array}$ & $\begin{array}{c}2.19 \\
(4.65)\end{array}$ & $\begin{array}{l}.17^{* *} \\
(.06)\end{array}$ & $\begin{array}{l}-2.07 \\
(3.52)\end{array}$ \\
\hline College degree & $\begin{array}{l}.06 \\
(.07)\end{array}$ & $\begin{array}{l}12.63^{*} \\
(5.70)\end{array}$ & $\begin{array}{l}.08 \\
(.09)\end{array}$ & $\begin{array}{c}1.92 \\
(4.57)\end{array}$ & $\begin{array}{l}.39^{* * *} \\
(.07)\end{array}$ & $\begin{array}{l}16.23^{*} \\
(7.81)\end{array}$ \\
\hline Advanced degree & $\begin{array}{l}.14 \\
(.10)\end{array}$ & $\begin{array}{l}13.15 \\
(9.33)\end{array}$ & $\begin{array}{l}.02 \\
(.14)\end{array}$ & $\begin{array}{c}3.25 \\
(7.77)\end{array}$ & $\begin{array}{l}.18 \\
(.10)\end{array}$ & $\begin{array}{c}13.68 \\
(10.82)\end{array}$ \\
\hline Father worked fulltime & $\begin{array}{l}.17^{\star \star \star} \\
(.04)\end{array}$ & $\begin{array}{c}3.70 \\
(2.60)\end{array}$ & $\begin{array}{l}.10^{*} \\
(.04)\end{array}$ & $\begin{array}{l}-5.60 \\
(4.41)\end{array}$ & $\begin{array}{l}.17^{\star * *} \\
(.05)\end{array}$ & $\begin{array}{r}4.80^{*} \\
(2.08)\end{array}$ \\
\hline Mother worked fulltime & $\begin{array}{l}-.02 \\
(.03)\end{array}$ & $\begin{array}{l}-2.00 \\
(1.98)\end{array}$ & $\begin{array}{l}-.06 \\
(.03)\end{array}$ & $\begin{array}{c}1.53 \\
(2.03)\end{array}$ & $\begin{array}{l}-.07^{*} \\
(.03)\end{array}$ & $\begin{array}{l}-3.29 \\
(1.77)\end{array}$ \\
\hline Father born in U.S. & $\begin{array}{l}-.09 \\
(.08)\end{array}$ & $\begin{array}{r}-12.03^{*} \\
(5.32)\end{array}$ & $\begin{array}{l}-.12 \\
(.09)\end{array}$ & $\begin{array}{c}1.21 \\
(2.29)\end{array}$ & $\begin{array}{l}-.23^{*} \\
(.09)\end{array}$ & $\begin{array}{l}-2.87 \\
(5.62)\end{array}$ \\
\hline Mother born in U.S. & $\begin{array}{l}.07 \\
(.08)\end{array}$ & $\begin{array}{l}-3.66 \\
(5.71)\end{array}$ & $\begin{array}{l}.08 \\
(.10)\end{array}$ & $\begin{array}{c}.54 \\
(3.93)\end{array}$ & $\begin{array}{l}.18 \\
(.09)\end{array}$ & $\begin{array}{l}-8.42 \\
(8.03)\end{array}$ \\
\hline Ever inherited & $\begin{array}{l}.07^{*} \\
(.03)\end{array}$ & $\begin{array}{r}4.75^{*} \\
(1.95)\end{array}$ & $\begin{array}{l}.33^{* * *} \\
(.04)\end{array}$ & $\begin{array}{c}-.75 \\
(2.35)\end{array}$ & $\begin{array}{l}.26^{* * *} \\
(.03)\end{array}$ & $\begin{array}{c}1.88 \\
(1.75)\end{array}$ \\
\hline Amount inherited & $\begin{array}{l}.00^{* *} \\
(.00)\end{array}$ & $\begin{array}{l}.00 * * * \\
(.00)\end{array}$ & $\begin{array}{l}.00^{* *} \\
(.00)\end{array}$ & $\begin{array}{l}.00 \\
(.00)\end{array}$ & $\begin{array}{l}.00^{* *} \\
(.00)\end{array}$ & $\begin{array}{c}.00 \\
(.00)\end{array}$ \\
\hline $\begin{array}{l}\text { Current residence } \\
\text { North central }\end{array}$ & $\begin{array}{r}.50 \\
(.04) \\
\end{array}$ & $\begin{array}{l}-7.44^{* *} \\
(2.80) \\
\end{array}$ & $\begin{array}{l}-.07 \\
(.05) \\
\end{array}$ & $\begin{array}{l}-3.17 \\
(3.05) \\
\end{array}$ & $\begin{array}{l}.00 \\
(.04) \\
\end{array}$ & $\begin{array}{l}-7.17^{* *} \\
(2.94) \\
\end{array}$ \\
\hline
\end{tabular}


Table 6 continued

\begin{tabular}{lcccccc}
\hline South & .43 & $-6.09^{*}$ & $-.21^{* * *}$ & -1.16 & -.04 & .22 \\
& $(.05)$ & $(2.87)$ & $(.06)$ & $(3.40)$ & $(.05)$ & $(3.94)$ \\
West & -.01 & 6.95 & $-.29^{* * *}$ & -3.22 & $-.19^{* * *}$ & -3.36 \\
& $(.05)$ & $(3.56)$ & $(.06)$ & $(3.32)$ & $(.05)$ & $(3.82)$ \\
Urban & -.24 & $-2.66^{*}$ & $.07^{*}$ & $4.30^{*}$ & .04 & 2.07 \\
& $(.03)$ & $(1.35)$ & $(.04)$ & $(1.99)$ & $(.04)$ & $(1.75)$ \\
$\chi^{2}$ & $9,007^{* * *}$ & $3,288^{* * *}$ & $5,413^{* * *}$ & $3,671^{* * *}$ & $4,432^{* * *}$ & $3,555^{* * *}$ \\
\hline
\end{tabular}

Notes: Standard errors are in parentheses. Sample is 4,753 non-Hispanic white respondents or $57,036\left(4,753^{\star} 12\right.$ years) observations. Also controlled but not displayed are age, gender, and a dichotomous indicator that the respondent did not report childhood family income. ${ }^{*} \mathbf{p}<.05{ }^{* *} \mathbf{p}<.01{ }^{* * *} \mathbf{p}<.001$

higher than that of Conservative Protestants and Mainline Protestants, suggesting that these assets play a central role in the portfolios of Catholics. On the contrary, Catholics are more likely to own stocks and mutual funds, but the value of their holdings is not significantly larger than for other groups.

\section{Conclusion}

Wealth mobility is an important process underlying wealth inequality. However, researchers have paid relatively little attention to wealth mobility, at least in part, because it is so rare. This research took advantage of the unique opportunity created by Roman Catholics in recent decades to focus on the relationship between religion and wealth mobility. I isolated non-Hispanic whites raised in Catholic families and explored whether they have been mobile and, if so, what factors have accounted for their changing position. I proposed that changing fertility, unique marriage patterns, upward mobility and unique values related to work and money combined to propel Catholics upward in the wealth distribution. Results show that non-Hispanic whites raised in Catholic families have accumulated relatively high wealth as adults, despite being raised in comparatively disadvantaged families. I also compared the intragenerational wealth mobility (1985-2000) of Catholics to the sample average and found that Catholics were significantly more likely than the average respondent to move up in the wealth distribution between early and later adulthood. Multivariate analyses supported my arguments that Catholics have high wealth compared to both Conservative and Mainline Protestants and that fertility, marriage, education and saving behaviors contributed to this relatively recent advantage.

Although it is rare for an entire group to make such a dramatic move in wealth distribution, the Catholic transformation is consistent with understanding of how this group has assimilated and changed on other important measures of well-being. White Catholics are largely descendents of Irish, Italian, German and Polish immigrants who arrived in the United States starting in the 1840s and initially settled in ethnic communities in medium to large cities in the Northeast (Alba 1981). Distance from the immigrant experience may have facilitated the 
fertility changes and education patterns, yet Catholics are still close enough to their ancestry to retain some of their values. Both male and female Catholic immigrants worked primarily in manufacturing jobs and quickly established themselves as hard working and reliable (Oats 1989). It is also notable that immigrant Catholic women participated in the labor force and in labor movements in relatively high numbers, primarily in textile and garment mills and as domestic servants. The early participation of women in the workforce set the stage for rather rapid assimilation by increasing household earnings and contributing to occupational opportunities (Kenneally 1989; Oats 1989). There is some evidence that Catholic immigrants also developed a pro-assimilation, pro-education ethic that they actively and consciously passed along to younger Catholics (Oats 1989). Research dating to the 1960s showed that Catholics were relatively disadvantaged compared to Mainline Protestants, but evidence that this gap has closed is mounting (Glenn and Hyland 1967; Lenski 1961; Sherkat and Ellison 1999). It is difficult to determine with certainty whether a pro-assimilation ethic contributed to this transformation, but it is clear that the change has been rather pronounced. The change in wealth ownership is consistent with this history.

What does this pattern suggest for the future trajectory of Catholics? If Catholics do have an instrumental attitude toward work and money (Tropman 2002), it is unlikely that they will continue to move upward in the wealth distribution. Other priorities - such as family - will continue to be more important, and Catholics will simply accumulate enough wealth to have a secure financial cushion. Moreover, if their propensity to invest in relatively low risk assets is an enduring preference rather than a characteristic of an upwardly mobile group, the upward wealth trajectory is unlikely to continue at the rate it has in the past. Rather, it is likely that Catholics will continue to accumulate assets much like Mainline Protestants, making the two groups increasingly similar. Alternatively, if recent Catholic attitudes toward work and money reflect their working class past, it is possible that increasing numbers of Catholics will move into the highest levels of the wealth distribution. If Catholics continue to excel in education, for example, they will continue to gain occupational prestige and to adopt attitudes toward work and money that are similar to Mainline Protestants or Jews who are more likely to have pro-accumulation attitudes. If this happened, Catholics might continue to earn higher income and ultimately to accumulate greater wealth. Of course, these are questions that future research might explore.

Future research might extend this study to examine other long-term trends. Divorce rates among Catholics are likely to rise over time, and growth in educational attainment and income is likely to level off. Each of these would decrease the rate of wealth accumulation for Catholics and might affect their position in the distribution. In addition, there is evidence that religion shapes mortality (Hummer, et al. 1999), and longevity is an important determinant of total lifetime wealth accumulation. Future research might explore whether mortality differences mediate or exacerbate the Catholic advantage and might explore changes in this relationship as the upwardly mobile Catholics age. Future research might also look at the role of religious change in Catholic wealth accumulation. My preliminary estimates suggested that both Catholics who remained in the church as adults and those who left the church enjoyed a wealth advantage. Yet 
there is very good evidence that religious change matters for other outcomes (Ellison and Sherkat 1990; Sherkat 1991, 2001; Sherkat and Ellison 1991), and there may be other more nuanced and instructive differences between Catholics by adult religious status that are worth exploring. Similarly, it would be useful to compare patterns of wealth accumulation by race and ethnicity for Catholics. Again, there is important evidence that race interacts with religion in instructive ways (Ellison and Sherkat 1990; Sherkat and Ellison 1991), and these ideas could usefully be extended to studies of wealth ownership.

Finally, future research might explore the role that religiosity, identity as a Catholic, and other elements of the strength of the religious experience play in the wealth accumulation and mobility process. Religious attendance can be used to measure the degree to which people were exposed to religious messages and teachings, and these measures might suggest whether exposure to doctrine is the true cause of group differences. In preliminary analyses, this research explored interactions between attendance and affiliation. Findings indicate that attendance strengthened the effect of affiliation slightly, but the affiliation effect was much stronger and would essentially eliminate the attendance effect when both were entered separately. Future research might investigate parsing out the unique effects of attendance with a data set that includes more detailed information about religious attendance and the related issue of religiosity (not included in the NLS-Y).

These findings may appear to address the simple relationship between childhood religion and adult wealth, but they are at the core of what is valuable about sociological research. Wealth ownership is a critical outcome that has received far too little attention from sociologists. Studies of inequality focus too often on income and wages, and they neglect savings. Wealth is often associated with those who have considerable amounts of money, but assets are essential for all families. The loss of an income earner, an unexpected illness, or another financial emergency can be devastating to a family with no savings. Nearly 20 percent of U.S. households have zero or negative net worth and could face this sort of crisis with little warning. Of course, wealth also matters because it can be used to buy safety, a pleasant living environment, educational and occupational advantages and because it can be passed to future generations. This paper also underscores the importance of religion in shaping well-being. The role of religion in producing socio-economic outcomes, in particular, has attracted little attention. Yet as this research shows, there are clear patterns between religious background and adult traits that persist after adult behaviors and processes are controlled. My findings also highlight the importance of intergenerational processes. Sociologists are well aware that family background matters, and this research highlights elements of both background and adult well-being critical to understanding how intergenerational processes play out. Finally, this article offers more general insight into how traits and processes in the family of origin affect adult outcomes. Understanding how religion in the family of origin affects adult well-being may provide insight into how other family traits and processes (e.g., race, size, composition) affect wealth and other adult outcomes. 


\section{Notes}

1. All values are in $\mathbf{2 0 0 0}$ dollars. Author's estimates from the Survey of Consumer Finances.

2. I focus on non-Hispanic whites raised as Roman Catholics throughout the paper because minority Catholics did not experience comparable levels of upward mobility. I refer to this group as Catholic to conserve space.

3. While some have raised important objections (Morgan 2001; Morgan and Sorensen 1999), the relationship between attending Catholic school and educational achievement is highly robust.

4. Indeed, there are female Doctors of the Church, a title given to some Catholic saints whose writings have contributed significantly to Church teaching. Thirty-three ecclesiastical writers have this title, including three women: Catherine of Siena, Teresa of Avila and Therese of Lisieux.

5. Missing data reduced my sample size slightly, but I found no significant wealth or religion differences between my sample and the full sample. Experiments with imputing missing data did not change the results. I omitted 58 firstgeneration immigrants in order to isolate the effect of being raised in an American Catholic family on wealth ownership and to avoid biasing the data with self-selecting, high-status overachievers. Omitting recent immigrants did not change the findings.

6. The survey did not include wealth questions in 1991.

7. Using other indicators such as years of education produced substantively similar results. I opted to model attainment of bachelor's and advanced degrees because, for the generation that included parents of the NLSY sample, these are important indicators of high socioeconomic status. Modeling the completion of a bachelor's degree and advanced degrees separately produced comparable results, although very few mothers and relatively few fathers had advanced degrees.

8. I experimented with modeling family income, parents' occupational prestige, residential traits and other indicators of well-being. The results were substantively the same as the results I present.

9. The results were robust to alternative definitions of wealth such as gross assets (the sum of assets not reduced by debts), total financial assets, total non-financial assets and total liabilities.

10. Excluding other possessions does not change the results significantly.

11. I used the Consumer Price Index (CPI) to adjust all asset and debt values to 2000 dollars.

12. Removing outliers did not change the results.

13. The NLS-Y asked about religious affiliation in 1979, 1982 and 2000. I used 1979 reports because they provided the greatest denominational detail, 
and the three reports are highly consistent with each other. The distribution of respondents across denominations is also consistent with other data sources, including the General Social Survey.

14. Controlling for ages, spacing and gender of children does not improve the models.

15. Age at first marriage was not a significant predictor of wealth.

16. I opted to include the dummy indicators to illustrate the relevance of various discrete education levels to wealth ownership, but substituting a continuous variable produced comparable results.

17. I standardized, logged and converted this variable to 2000 dollars using the $\mathrm{CPI}$. Including those who did not inherit (i.e., those with a zero value) did not appreciably change the results. While it can be difficult to generate accurate estimates of inheritance, the NLS-Y estimates are consistent with measures of inherited wealth in other studies (McNamee and Miller, 1998).

18. I did not control for the square of age because wealth accumulation does not typically follow the standard curvilinear relationship with age that income does. Preliminary investigation confirmed that the squared age term was not a significant predictor of asset ownership in these data.

19. Controlling for residence in New York City, Boston and other locations including northeastern and north central locations that have large Catholic populations did not change the results. While Catholic respondents were more likely than others to be born in the northeast or north central states, they have relocated throughout the United States. Controlling for regional differences in place of birth, place of residence in each survey year, changes in residence, recent changes in residence, place of residence at significant points in life (e.g., education, first job, subsequent jobs, birth of first child, birth of subsequent children, first marriage, subsequent marriages, etc.) and at significant points in the accumulation trajectory (e.g., first home purchase, most recent home purchase) did not change the results. Controlling for housing price variations, using either median home values or the conventional mortgage home price index, did not improve model fit.

20. The White's Test for heteroskedasticy was significant, and the Ordinary Durbin-Watson Test (D-W) for first-order autocorrelation was significantly different from two. Because the Ordinary D-W was significant, it was not necessary to use the General D-W for high-orders of autocorrelation.

21. The name mixed model refers to the estimation of both fixed-effects parameters, $\beta$, and random-effect parameters, $\gamma$.

22. The proportion of the respondents in each of the religious groups is consistent with estimates from other data sources, including the General Social Survey. 
23. Using other measures such as number of years of school completed produces similar patterns.

24. I used 1985 as a starting point because all respondents were at least 20 years old in that year and could be considered adults, and I used 2000 as the end year because it is the most recent year for which data are available. These points capture the sample at early adulthood and when most were in their prime working years and had at least begun to establish their net worth portfolios.

25. Cox tests confirm that differences across models in the effect of the Catholic indicator are statistically significant.

26. Again, Cox tests confirm that this difference is statistically significant.

27. Cox tests confirm that this difference is significant.

28. The stocks and mutual funds category is representative of financial assets. Using other financial assets such as bonds, Certificates of Deposit or checking or savings accounts produced comparable results.

\section{References}

Aizcorbe, Ana M., Arthur B. Kennickell and Kevin B. Moore. 2001. "Recent Changes in U.S. Family Finances: Evidence from the 1998 and 2001 Survey of Consumer Finances." Washington, DC: the Federal Reserve Board.

Alba, Richard D. 1981. "The Twilight of Ethnicity among American Catholics of European Ancestry." Annals of the American Academy of Political and Social Science 454:86-97.

Alwin, Duane. 1986. "Religion and Parental Childbearing Orientations: Evidence for a Catholic-Protestant Convergence." American Journal of Sociology 92:412-20.

Borjas, George J. 1999. Heaven's Door: Immigration Policy and the American Economy. Princeton University Press.

. editor. 2000. Issues in the Economics of Immigration. University of Chicago Press.

Bryk, Anthony S., Valerie E. Lee and Peter B. Hollan. 1993. Catholic Schools and the Common Good. Harvard University Press.

Call, Vaughn R.A., and Tim B. Heaton. 1997. "Religious Influence on Marital Stability." Journal for the Scientific Study of Religion 36:382-92.

Chaves, Mark, and Sharon L. Miller, editors. 1999. Financing American Religion. AltaMira Press. 
Coleman, James S., Thomas Hoffer and Sally Kilgore. 1982a. "Achievement and Segregation in Secondary Schools: A Further Look at Public and Private School Differences." Sociology of Education 55:162-82.

. 1982b. "Cognitive Outcomes in Public and Private Schools." Sociology of Education 55:65-76.

Coleman, John A. 1993. One Hundred Years of Catholic Social Thought. Orbis Books.

Curtis, Kristen Taylor, and Christopher G. Ellison. 2002. "Religious Heterogamy and Marital Conflict: Findings from the National Survey of Families and Households." Journal of Family Issues 23:551-76.

D'Antonio, William V., James D. Davidson, Dean R. Hoge and Katherine Meyer. 2001. American Catholics: Gender, Generation, and Commitment. Altamira Press.

Darnell, Alfred, and Darren E. Sherkat. 1997. "The Impact of Protestant Fundamentalism on Educational Attainment." American Sociological Review 62:306-15.

DeBerri, Edward P., and James E. Hug. 2003. Catholic Social Teaching: Our Best Kept Secret, Fourth Edition. Orbis Books.

Diggle, Peter L., Kung-Yee Liang and Scott L. Zeger. 1994. Analysis of Longitudinal Data. Clarendon.

Downey, Douglas B. 1995. "When Bigger is Not Better: Family Size, Parental Resources, and Children's Educational Performance." American Sociological Review 60:746-61.

Ellison, Christopher G., and Darren E. Sherkat. 1990. "Patterns of Religious Mobility among Black Americans." Sociological Quarterly 31:551-68.

Evans, William N., and Robert M. Schwab. 1995. "Finishing High School and Starting College: Do Catholic Schools Make a Difference?" The Quarterly Journal of Economics 110:941-74.

Featherman, David L. 1971. "The Socioeconomic Achievement of White ReligioEthnic Subgroups: Social and Psychological Explanations." American Sociological Review 36:207-22.

Filsinger, Erik E., and Margaret R. Wilson. 1984. "Religiosity, Socioeconomic Rewards, and Family Development: Predictors of Marital Adjustment." Journal of Marriage and the Family 46:663-70.

Glenn, Norval D., and Ruth Hyland. 1967. "Religious Preference and Worldly Success: Some Evidence from National Surveys." American Sociological Review 32:73-85. 
Greeley, Andrew M. 1969. "Continuities in Research on the 'Religious Factor'." American Journal of Sociology 75:355-59.

. 1979. "The Sociology of American Catholics." Annual Review of Sociology 79:91-111.

. 1989. "Protestant and Catholic: Is the Analogical Imagination Extinct?" American Sociological Review 54:485-502.

2004. The Catholic Revolution: New Wine, Old Wineskins, and the Second Vatican Council. University of California Press.

Hamington, Maurice. 1995. Hail Mary? The Struggle for Ultimate Womanhood in Catholicism. Routledge.

Hammond, Judith A., Bettie S. Cole and Scott H. Beck. 1993. "Religious Heritage and Teenage Marriage." Review of Religious Research 35:117-33.

Hoffer, Thomas, Andrew M. Greeley and James S. Coleman. 1985. "Achievement Growth in Public and Catholic Schools." Sociology of Education 58:74-97.

Hummer, Robert A., Richard G. Rogers, Charles B. Nam and Christopher G. Ellison. 1999. "Religious Involvement and U.S. Adult Mortality." Demography 36:273-85.

Keister, Lisa A. 2003a. "Religion and Wealth: The Role of Religious Affiliation and Participation in Early Adult Asset Accumulation." Social Forces 82:173-205.

. 2003b. "Sharing the Wealth: Siblings and Adult Wealth Ownership." Demography 40:521-42.

2005. Getting Rich: America's New Rich and How they Got that Way. Cambridge University Press.

. Forthcoming. "Childhood Religious Denomination and Early Adult Asset Accumulation." Religion, Families, and Health: New Directions in Population-Based Research. C.G. Ellison and R.A. Hummer, editors. Rutgers University Press.

Kennelly, James J. 1989. "A Question of Equality." Pp. 125-51. American Catholic Women: A Historical Exploration. Karen Kennelly, editor. Macmillan.

Lehrer, Evelyn L. 1996. "Religion as a Determinant of Fertility." Journal of Population Economics 9:173-96.

1998. "Religious Intermarriage in the United States: Determinants and Trends." Social Science Research 27:245-63.

. 1999. "Religion as a Determinant of Educational Attainment: An Economic Perspective." Social Science Research 28:358-79. 
Lehrer, Evelyn L., and Carmel U. Chiswick. 1993. "Religion as a Determinant of Marital Stability." Demography 30:385-404.

Lenski, Gerhard. 1961. The Religious Factor: A Sociological Study of Religion's Impact on Politics, Economics, and Family Life. Doubleday.

Marcum, John P. 1981. "Explaining Fertility Differences among U.S. Protestants." Social Forces 60:532-43.

. 1986. "Explaining Protestant Fertility: Belief, Commitment, and Homogamy." Sociological Quarterly 27:547-58.

McNamee, Stephen J., and Robert K. Miller, Jr. 1998. "Inheritance and Stratification." Pp. 193-213. Inheritance and Wealth in America. R.K. Miller, Jr. and S.J. McNamee, editors. Plenum Press.

Mosher, William D., Linda B. Williams and David P. Johnson. 1992. "Religion and Fertility in the United States: New Patterns." Demography 29:199-214.

Neal, Derek. 1997. "The Effect of Catholic Secondary Schooling on Educational Achievement." Journal of Labor Economics 15:98-123.

Nelson, Phillip J., and Kenneth V. Greene. 2003. Signaling Goodness: Social Rules and Public Choices. University of Michigan Press.

Oats, Mary J. 1989. "Catholic Laywomen in the Labor Force, 1850-1950." Pp. 81124. American Catholic Women. K. Kennelly, editor. MacMillan.

Pearce, Lisa D. Forthcoming. "Religion's Impact on the Timing of First Births in the U.S." Religion, Families, and Health: New Directions in Population-Based Research. C.G. Ellison and R.A. Hummer, editors. Rutgers University Press.

Regnerus, Mark D., Christian Smith and David Sikkink. 1998. "Who Gives to the Poor? The Influence of Religious Tradition and Political Location on the Personal Generosity of Americans Toward the Poor." Journal for the Scientific Study of Religion 37:481-93.

Roof, Wade Clark. 1979. "Socioeconomic Differences among White Socioreligious Groups in the United States." Social Forces 58:280-89.

Sandefur, Gary D., and Thomas Wells. 1999. "Does Family Structure Really Influence Educational Attainment?" Social Science Research 28:331-57.

Sander, William. 1995. The Catholic Family: Marriage, Children, and Human Capital. Westview Press.

Sherkat, Darren E. 2004. "Religious Intermarriage in the United States: Trends, Patterns, and Predictors." Social Science Research 33:606-25.

. 1991. "Leaving the Faith: Testing Theories of Religious Switching Using Survival Models." Social Science Research 20:171-87. 
2001. "Tracking the Restructuring of American Religion: Religious Affiliation and Patterns of Religious Mobility, 1973-1998." Social Forces 79:1459-93.

Sherkat, Darren E., and Christopher G. Ellison. 1991. "The Politics of Black Religious Change: Disaffiliation from Black Mainline Denominations." Social Forces 70:431-54.

. 1999. "Recent Developments and Current Controversies in the Sociology of Religion." Annual Review of Sociology 25:363-94.

Steen, Todd P. 1996. "Religion and Earnings: Evidence from the NLS Youth Cohort." International Journal of Social Economics 23:47-58.

Steensland, Brian, Jerry Z. Park, Mark D. Regnerus, Lynn D. Robinson, W. Bradford Wilcox and Robert D. Woodberry. 2000. "The Measure of American Religion: Toward Improving the State of the Art." Social Forces 79:291-318.

Swidler, Ann. 1986. "Culture in Action: Symbols and Strategies." American Sociological Review 51:273-86.

Thibodeau, Richard, and Edward J. O'Donnell with John C. O'Connor. 1997. The Essential Catholic Handbook: A Summary of Beliefs, Practices, and Prayers. Liguori Publications.

Tropman, John E. 1995. The Catholic Ethic in American Society: An Exploration of Values. Jossey-Bass.

. 2002. The Catholic Ethic and the Spirit of Community. Georgetown University Press.

Weber, Max. 1930. The Protestant Ethic and the Spirit of Capitalism. Harper Collins.

Wuthnow, Robert. 1994. God and Mammon in America. Free Press.

Wuthnow, Robert, and Tracy L. Scott. 1997. "Protestants and Economic Behavior." Pp. 260-95. New Directions in American Religious History. H.S. Sout and D.G. Hart, editors. Oxford University Press.

Zelizer, Viviana. 1978. "Human Values and the Market: The Case of Life Insurance and Death in 19th-Century America." American Journal of Sociology 84:591-610.

. 1989. "The Social Meaning of Money: 'Special Monies'." American Journal of Sociology 95:342-77. 